WSRC-TR-98-00367, Rev. 0

\title{
Cesium Precipitation Kinetic Studies
}

by

M. J. Barnes

Westinghouse Savannah River Company

Savannah River Site

Aiken, South Carolina 29808

DOE Contract No. DE-AC09-96SR18500

This paper was prepared in connection with work done under the above contract number with the U. S.

Department of Energy. By acceptance of this paper, the publisher and/or recipient acknowledges the U.S. Government's right to retain a nonexclusive, royalty-free license in and to any copyright covering this paper, along with the right to reproduce and to authorize others to reproduce all or part of the copyrighted paper. 


\section{DISCLAIMER}

This report was prepared as an account of work sponsored by an agency of the United States Government. Neither the United States Government nor any agency thereof, nor any of their employees, makes any warranty, express or implied, or assumes any legal liability or responsibility for the accuracy, completeness, or usefulness of any information, apparatus, product, or process disclosed, or represents that its use would not infringe privately owned rights. Reference herein to any specific commercial product, process, or service by trade name, trademark, manufacturer, or otherwise does not necessarily constitute or imply its endorsement, recommendation, or favoring by the United States Government or any agency thereof. The views and opinions of authors expressed herein do not necessarily state or reflect those of the United States Government or any agency thereof.

This report has been reproduced directly from the best available copy.

Available to DOE and DOE contractors from the Office of Scientific and Technical Information, P.O. Box 62, Oak Ridge, TN 37831; prices available from (615) 576-8401.

Available to the public from the National Technical Information Service, U.S. Department of Commerce; 5285 Port Royal Road, Springfield, VA 22161. 


\section{DISCLAIMER}

Portions of this document may be illegible in electronic image products. Images are produced from the best available original document. 
WSRC-TR-98-00367, Rev. 0

\section{CESIUM PRECIPITATION KINETIC STUDIES}

M. J. Barnes

Publication Date: October 2, 1998

Westinghouse Savannah River Company

Savannah River Technology Center

A iken, SC 29808

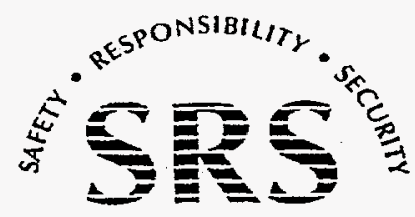

SAVANNAH RIVER SITE 
S. D. Fink

WSRC-TR-98-00367, Rev. 0

Page 2 of 20

CESIUM PRECIPITATION KINETIC STUDIES

Author
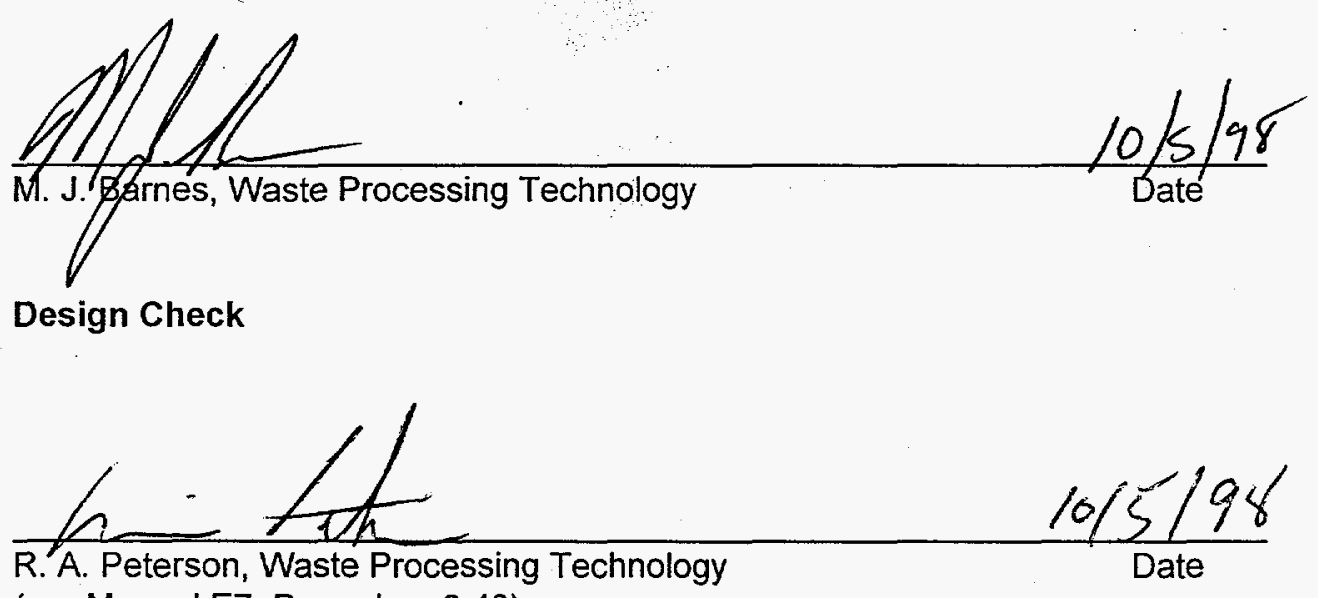
(per Manual E7, Procedure 2.40)

Approvals/Review
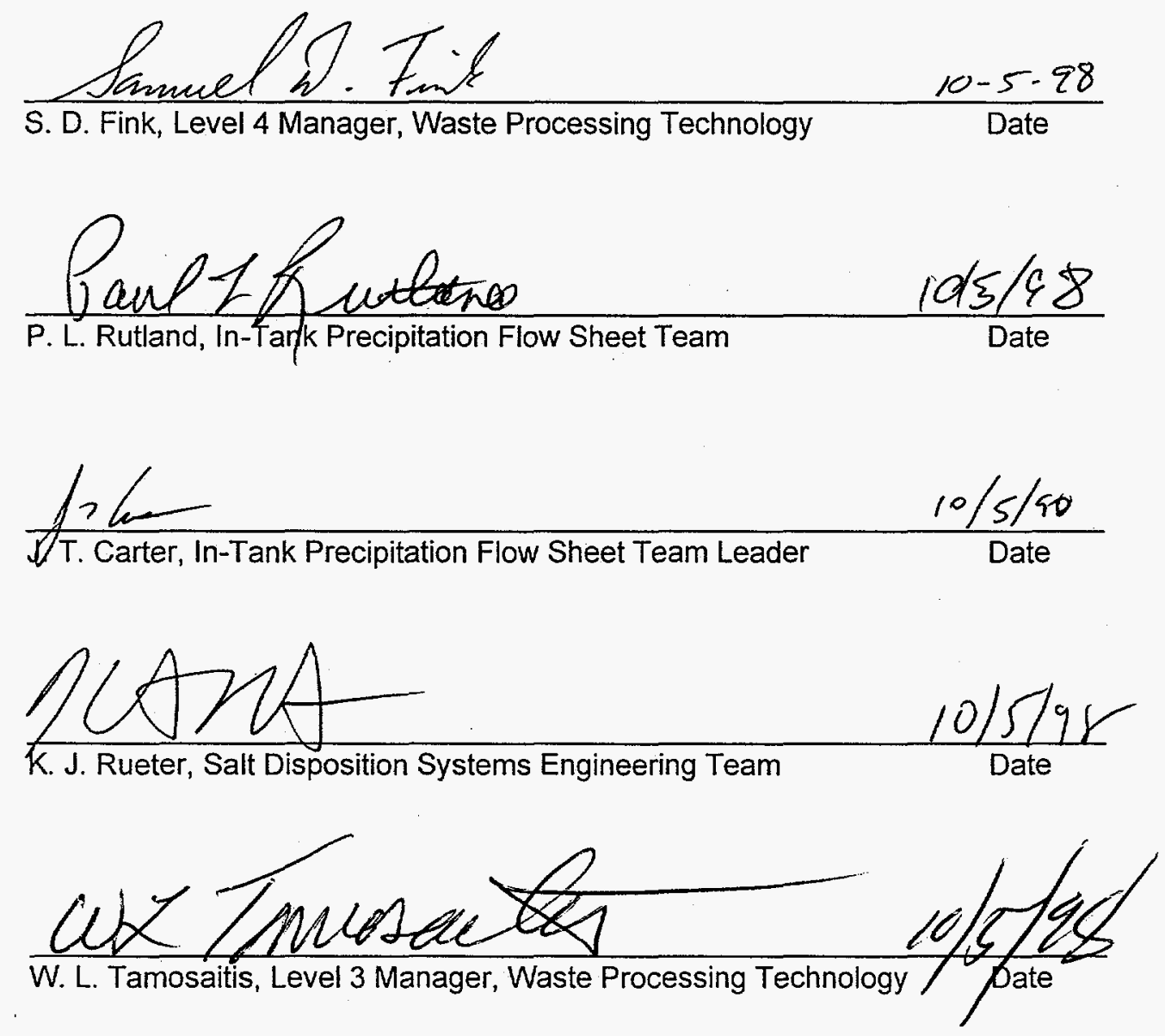


\subsection{Summary}

The data obtained from the tests described in this document provide results for determining tank size for in the proposed Small-Tank Tetraphenylborate (STTP) facility. The data clearly indicate the following.

- The degree of agitation during addition of NaTPB significantly affects the rate of cesium precipitation.

- The $\mathrm{Na}^{+}$concentration of the waste solution moderately affects the rate of cesium precipitation.

- The percent excess of NaTPB moderately affects the rate of cesium precipitation.

- The ratio of $\mathrm{K}^{+}$to $\mathrm{Cs}^{+}$and $\mathrm{Hg}^{2+}$ to $\mathrm{Cs}^{+}$only slightly influence the rate of cesium precipitation.

- Decontamination to a Cs-137 concentration below $30 \mathrm{nCi} / \mathrm{g}$ occurred in less than $1.5 \mathrm{~h}$ with a $100 \%$ excess of NaTPB in a $5.0 \mathrm{M} \mathrm{Na}^{+}$solution when stirred at a rate of $300 \mathrm{rpm}$. For the same solution composition and stirring speed but using $33 \%$ excess NaTPB, the decontamination required a longer time, but completed within $24 \mathrm{~h}$.

The study also examined the relative kinetics of mercury reaction with tetraphenylborate but chemical analyses remain incomplete at this time. A future revision of this report will detail those studies.

\subsection{Introduction}

The Salt Disposition Systems Engineering Team identified Small Tank Tetraphenylborate Precipitation (STTP) as one of the four alternatives to replace the In-Tank Precipitation Facility at the Savannah River Site. ${ }^{1}$ One economical uncertainty associated with the proposed STTP facility involves determination of tank size. Tank size and throughput depend on the kinetics of tetraphenylborate precipitation, and specifically on the time required to reach cesium decontamination. The High Level Waste Engineering (HLWE) Flow Sheet Team requested the Savannah River Technology Center (SRTC) examine cesium decontamination kinetics. ${ }^{2}$ This report details that study.

The work included the following objectives.

1) Obtain decontamination factor (DF) data to assist in defining size requirements for the Continuously Stirred Tank Reactors (CSTRs).

2) Confirm mercury precipitation occurs significantly faster than cesium decontamination.

3) Determine the amount of excess NaTPB required to provide high reliability in decontamination within 24 h cycle.

\subsection{Experimental}

This task consists of five sets of single effects tests examining the influence of potentially significant variables on tetraphenylborate precipitation kinetics. Test variables included sodium ion concentration $\left(\mathrm{Na}^{+}\right)$, the ratio of potassium ion concentration $\left(\mathrm{K}^{+}\right)$to cesium ion concentration $\left(\mathrm{Cs}^{+}\right)$, mercury ion concentration $\left(\mathrm{Hg}^{2+}\right)$, percent excess sodium tetraphenylborate $(\mathrm{NaTPB})$, and agitation rate. (Note: percent excess NaTPB refers to the amount of NaTPB required for precipitation of $\left.\mathrm{K}^{+}, \mathrm{Cs}^{+}, \mathrm{and}_{\mathrm{Hg}}{ }^{2+}\right)$. All tests used a similar procedure and equipment.

Personnel prepared stock solutions for each set of tests with an average salt composition. The following subsections describe the compositions used in each Test Set. The first four sets of tests varied a selected parameter at three levels maintaining the other variables constant. The last Test Set examined the effect of mixing. In all tests, personnel placed $100 \mathrm{~mL}$ of the respective solutions into $250 \mathrm{~mL}$ beakers and added cesium- 137 into the stock solutions at a concentration of $\sim 1.0 \times 10^{6} \mathrm{~d} / \mathrm{m} / \mathrm{mL}$. The tests added nonradioactive cesium, potassium, and mercury at the desired concentrations. In all tests, a variable speed paddle stirrer agitated the solution during the first 5 minutes of the precipitation reaction. The mixture stirred at $70 \mathrm{rpm}$ unless otherwise noted (Test Sets $E$ and $F$ used an initial rate of $300 \mathrm{rpm}$ ). Sodium tetraphenylborate solution $(0.55 \mathrm{M})$ addition to the agitated test solutions occurred at a rate of $3.0 \mathrm{~mL} / \mathrm{m}$

"Note: $1.0 \times 10^{6} \mathrm{~d} / \mathrm{m} / \mathrm{mL}$ equals $450 \mathrm{nCi} / \mathrm{mL}$ or $3.8 \times 10^{-8} \mathrm{M} \mathrm{Cs}$. The gamma counting detection limit used in this study to measure decontamination depended on sample size and counting time. For the conditions of these tests, the detection limit equaled $30 \mathrm{nCi} / \mathrm{g}$. 
using a peristaltic pump. After 5 minutes of reaction, personnel transferred the test mixtures to $125-\mathrm{mL}$ polyethylene bottles and placed in a pre-heated water bath/shaker at $25^{\circ} \mathrm{C}$. (Tests sets $A$ through $\mathrm{D}$ were continuously shaken gently while Test Set $F$ was shaken vigorously.) Periodically, approximately $5 \mathrm{~mL}$ or $15 \mathrm{~mL}$ samples were removed using a syringe, filtered using 0.45 micron disposable syringe filters, and submitted for analysis. Routine analytical protocols ${ }^{3}$ were used to determine the concentration of $\mathrm{Cs}^{+}$ (gamma counting), $\mathrm{K}^{+}$(atomic adsorption), and $\mathrm{Hg}^{2+}$ (atomic adsorption) in each test.

Personnel prepared test solutions from reagent grade chemicals using calibrated balances checked daily before use. The weights used for balance checks received calibration by the SRTC Standards Laboratory. The accuracy of glassware used to measure volumes was verified by gravimetric methods using water as a standard. Temperature measurements used equipment calibrated by the SRTC Standards Laboratory. Temperature monitoring occurred at least once per day to ensure a constant temperature reading within a range of $\pm 1^{\circ} \mathrm{C}$. All M\&TE used in this task received calibration or verification for accuracy prior to their use. Blanks and control samples were submitted for analysis to monitor preparations and analytical methods. Blanks consisted of stock solutions of the salt matrix. Control samples contained a defined quantity of the analyte of interest in the salt matrix. All pertinent instructions, results, and calculations were recorded in a numbered notebook (WSRC-NB-98-00122) in accordance with Manual L1, SRTC Procedures Manual, procedure 4.19. ${ }^{4}$ Laboratory notebook provide lifetime storage as a record.

\subsection{Test Set A: Effect of Sodium Concentration}

Test Set $\mathrm{A}$ investigated the effect of varying $\mathrm{Na}^{+}$on cesium precipitation. The set include three tests with different $\mathrm{Na}^{+}$concentrations $(4.0 \mathrm{M}, 5.0 \mathrm{M}$, and $6.0 \mathrm{M})$. The $\mathrm{K}^{+}, \mathrm{Cs}^{+}$, and $\mathrm{Hg}^{2+}$ concentrations, percent excess NaTPB, and initial rate of agitation $(70 \mathrm{rpm})$ remained constant. The following table shows the test design. Tests occurred in duplicate. Table 1 of Section 7 shows the compositions of the three salt solutions.

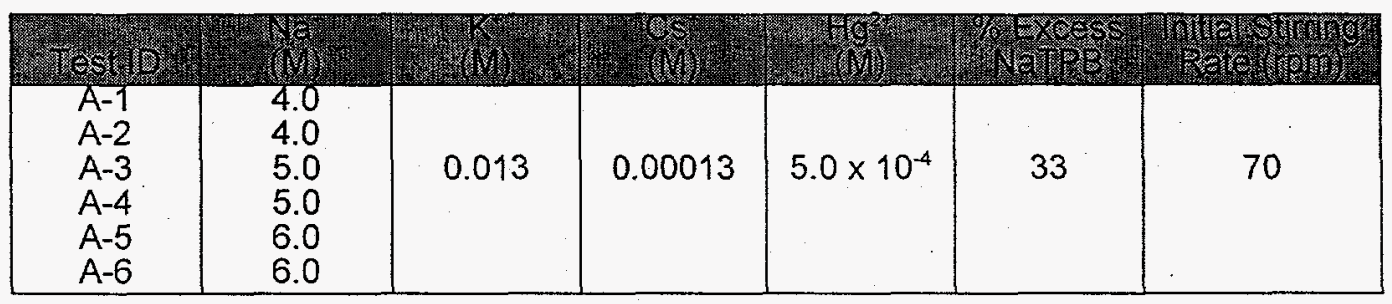

\subsection{Test Set B: Effect of Potassium Concentration}

These tests examined the effect of varying the $\mathrm{K}^{+}$to $\mathrm{Cs}^{+}$ratio on cesium precipitation. The three tests used different $\mathrm{K}^{+}$concentrations $\left(0.0033,0.013\right.$, and $0.052 \mathrm{M}-25: 1,100: 1$, and $400: 1 \mathrm{~K}^{+}: \mathrm{Cs}^{+}$ratio, respectively) while keeping the $\mathrm{Na}^{+}, \mathrm{Cs}^{+}$, and $\mathrm{Hg}^{2+}$ concentrations, percent excess $\mathrm{NaTPB}$, and initial rate of agitation $(70 \mathrm{rpm})$ constant. Personnel performed the tests in duplicate. The following table shows the test design. Table 2 of Section 7 defines the composition of the test solutions.

\begin{tabular}{|c|c|c|c|c|c|c|}
\hline Test ID & (M) & $(M)$ & $\begin{array}{l}G s \\
(\mathrm{M})\end{array}$ & (19) & $\begin{array}{l}\text { Excess } \\
\text { NateB }\end{array}$ & $\begin{array}{l}\text { Inital Strring } \\
\text { Rate (rpr) }\end{array}$ \\
\hline $\begin{array}{l}\text { B-1 } \\
\text { B-2 } \\
\text { B-3 } \\
\text { B-4 } \\
\text { B-5 } \\
\text { B-6 }\end{array}$ & 5.0 & $\begin{array}{l}0.0033 \\
0.0033 \\
0.013 \\
0.013 \\
0.052 \\
0.052\end{array}$ & 0.00013 & $5.0 \times 10^{-4}$ & 33 & 70 \\
\hline
\end{tabular}

\subsection{Test Set C: Effect of Mercury Concentration}

These tests examined the effect of varying the $\mathrm{K}^{+}$to $\mathrm{Cs}^{+}$ratio on cesium precipitation. The three tests used different $\mathrm{K}^{+}$concentrations $\left(0.0033,0.013\right.$, and $0.052 \mathrm{M}-25: 1,100: 1$, and $400: 1 \mathrm{~K}^{+}: \mathrm{Cs}^{+}$ratio, respectively) while keeping the $\mathrm{Na}^{+}, \mathrm{Cs}^{+}$, and $\mathrm{Hg}^{2+}$ concentrations, percent excess $\mathrm{NaTPB}$, and initial rate of agitation $(70 \mathrm{rpm})$ constant. Personnel performed the tests in duplicate. The following table shows the test design. Table 2 of Section 7 defines the composition of the test solutions. 


\begin{tabular}{|c|c|c|c|c|c|c|}
\hline Tesili & (iv) & (M) & $\frac{\cos }{m}$ & $\begin{array}{c}15 g \\
(\mathrm{M})\end{array}$ & $\begin{array}{l}\text { vexcess } \\
\text { Natri }\end{array}$ & $\begin{array}{l}\text { Titialstiring } \\
\text { Rate (rpm) }\end{array}$ \\
\hline $\begin{array}{l}\text { C-1 } \\
\text { C-2 } \\
\text { C-3 } \\
\text { C-4 } \\
\text { C-5 } \\
\text { C-6 }\end{array}$ & 5.0 & 0.013 & 0.00013 & $\begin{array}{l}1.2 \times 10^{-4} \\
1.2 \times 10^{-4} \\
5.0 \times 10^{-4} \\
5.0 \times 10^{-4} \\
20 \times 10^{-4} \\
20 \times 10^{-4}\end{array}$ & 33 & 70 \\
\hline
\end{tabular}

\subsection{Test Set D: Effect of Percent Excess Sodium Tetraphenylborate}

Personnel studied the influence of excess NaTPB on the cesium precipitation. Experiments used different percents of excess NaTPB $(33,67,78,100 \%)$ according to the following design. Personnel only repeated the tests with 33 and $100 \%$ excess NaTPB in this series. Table 4 (Section 7) provides the relevant compositions.

\begin{tabular}{|c|c|c|c|c|c|c|}
\hline Testin & (M) & $(\mathrm{M})$ & (M) & $\frac{19}{(M)}$ & $\begin{array}{l}\text { axcess } \\
\text { natPe }\end{array}$ & $\begin{array}{l}\text { Intal Strring } \\
\text { Rate (cpm) }\end{array}$ \\
\hline $\begin{array}{l}D-1 \\
D-2 \\
D-3 \\
D-4 \\
D-5 \\
D-6\end{array}$ & 5.0 & 0.013 & 0.00013 & $5.0 \times 10^{-4}$ & $\begin{array}{c}33 \\
33 \\
67 \\
78 \\
100 \\
100\end{array}$ & 70 \\
\hline
\end{tabular}

\subsection{Test Set F: Effect of Increased Agitation}

The work investigated the influence of mixing in replicated tests using different percents of excess NaTPB (33 and $100 \%)$. These experiments were stirred rapidly $(300 \mathrm{rpm})$ with a paddle stirrer for 5 minutes at the start of testing. The test design follows while Table 5 (Section 7) provides additional detail.

\begin{tabular}{|c|c|c|c|c|c|c|}
\hline Test D & $\begin{array}{l}\text { NE } \\
\text { (Wi) }\end{array}$ & $(\mathrm{M})$ & $\begin{array}{l}e_{S} \\
(m)\end{array}$ & $\left(\frac{\mathrm{gg}}{(\mathrm{u})}\right)$ & $\begin{array}{l}\text { fexcess } \\
\text { Nates }\end{array}$ & $\begin{array}{l}\text { Initialstirng } \\
\text { Rate (rom) }\end{array}$ \\
\hline F-1 & & & & & 33 & \\
\hline $\begin{array}{l}F-2 \\
F-3 \\
F-4\end{array}$ & 5.0 & 0.013 & 0.00013 & $5.0 \times 10^{-4}$ & $\begin{array}{c}33 \\
100 \\
100\end{array}$ & 300 \\
\hline
\end{tabular}

\subsection{Results and Discussion}

All tests used a starting concentration of total (i.e., radioactive plus non-radioactive) cesium of $0.00013 \mathrm{M}$. Each test solution contained $1.0 \times 10^{6} \mathrm{~d} / \mathrm{m} / \mathrm{mL}$ (i.e., $450 \mathrm{nCi} / \mathrm{mL}, 380 \mathrm{nCi} / \mathrm{g}$, or $3.8 \times 10^{-8} \mathrm{M}$ ) of cesium-137. The total cesium approximately equals that expected in SRS waste. However, the starting radioactive cesium concentration in these tests represents 750 times less than expected in SRS waste (assuming Cs137 constitutes $22 \%$ of the total cesium). The appendices contain the measured initial cesium for the experiments. The appendices also shows the equivalent cesium values assuming starting conditions equal to that for the radioactive waste, denoted as 'STTP Theoretical' where

$$
\text { STTP Theoretical }=756{ }^{*} \mathrm{Cs}-137 \text { (measured). }
$$

The remainder of this document will only refer to the STTP theoretical Cs-137 concentration when discussing decontamination of cesium. (Note $\mathrm{K}^{+}$and $\mathrm{Hg}^{2+}$ data analyses continue as this document goes to publication. A future revision of the report will contain that information.).

\subsection{Test Set A: Effect of Sodium Concentration}

Appendix $A$ and Figure 1 contain the data from Test Set $A$. Examination of Figure 1 indicates that the time required to reduce the Cs-137 concentration to less than $30 \mathrm{nCi} / \mathrm{g}$ depends upon the $\mathrm{Na}^{+}$. Only Tests $\mathrm{A}-1$ and A-2, with $33 \%$ excess NaTPB at $4.0 \mathrm{M}$ sodium, that achieved a $30 \mathrm{nCi} / \mathrm{g}$ limit during 72 hours of testing. This dependence likely reflects the rate of dissolution of insoluble NaTPB. The solubility of $\mathrm{NaTPB}$ depends on sodium concentration. The solubility of NaTPB $4.0 \mathrm{M}$ salt solution significantly exceeds that for 5.0 or $6.0 \mathrm{M}$ solution and hence the dissolution rate may prove much faster in these dilute solutions. However, even in a $4.0 \mathrm{M} \mathrm{Na}^{+}$solution, the time required to achieve a $30 \mathrm{nCi} / \mathrm{g}$ limit fell between 24 and 48 hours for these mild mixing conditions and limited excess NaTPB. 


\subsection{Test Set B: Effect of Potassium Concentration}

Figure 2 shows the data from Test Set B. (Appendix B for numerical data.) The data indicate that the relative concentration of potassium shows minor influence on the rate of precipitation of cesium. No tests in this series removed cesium to the target final value within 72 hours. The observation that cesium

Figure 1. Small Tank Tetraphenylborate Precipitation theoretical concentration of Cs-137 as a function of time and $\mathrm{Na}^{+}$. Tests $\mathrm{A}-1$ and $\mathrm{A}-2$ contained 4.0 $\mathrm{M} \mathrm{Na}^{+}, \mathrm{A}-3$ and $\mathrm{A}-4$ used $5.0 \mathrm{M} \mathrm{Na}^{+}$, while $\mathrm{A}-5$ and $\mathrm{A}-6$ held $6.0 \mathrm{M} \mathrm{Na}^{+}$.

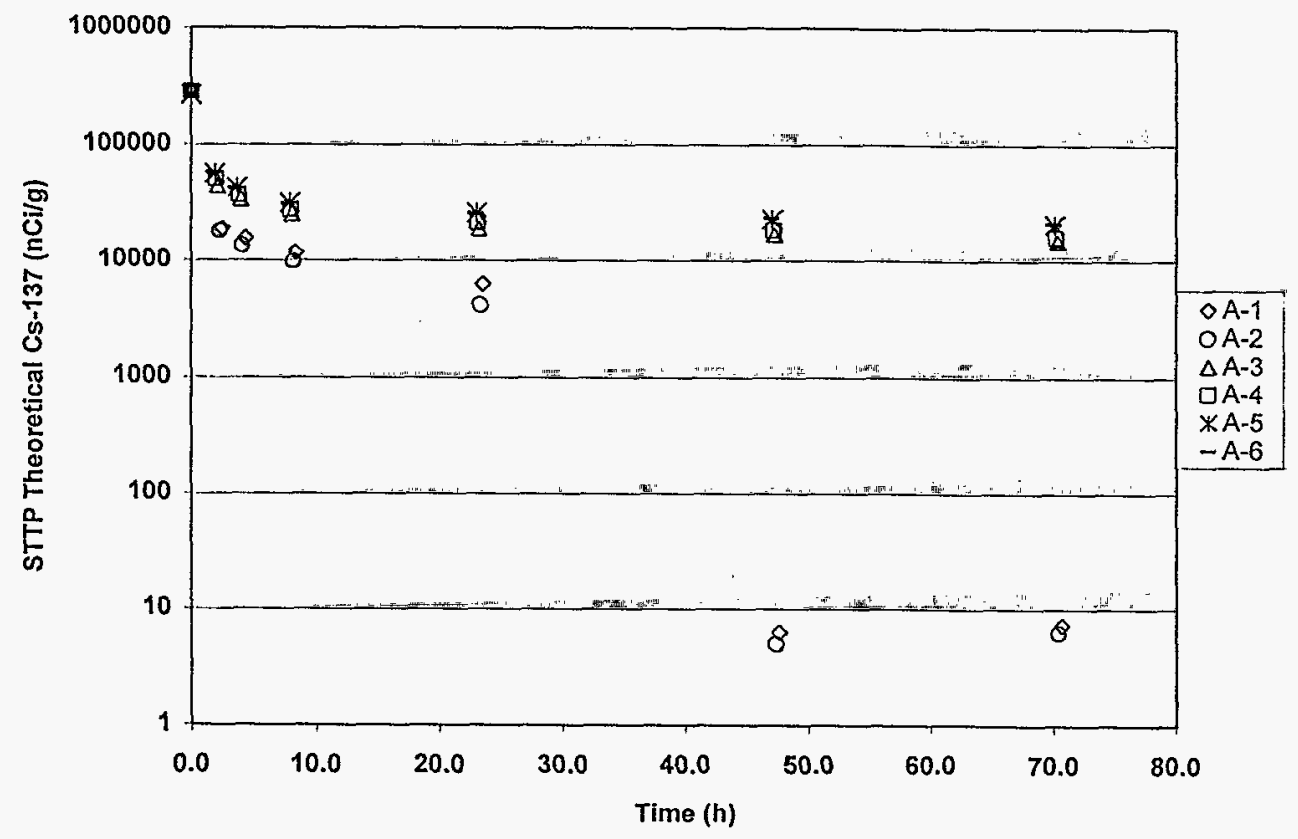

Figure 2. Small Tank Tetraphenylborate Precipitation theoretical concentration of Cs-137 as a function of time and $\mathrm{K}^{+}$. Tests $\mathrm{B}-1$ and $\mathrm{B}-2$ contained $0.0033 \mathrm{M} \mathrm{K}^{+}, \mathrm{B}-3$ and $\mathrm{B}-4$ used $0.013 \mathrm{M} \mathrm{K}^{+}$, while $\mathrm{B}-$ 5 and $\mathrm{B}-6$ held $0.052 \mathrm{M} \mathrm{K}^{+}$.

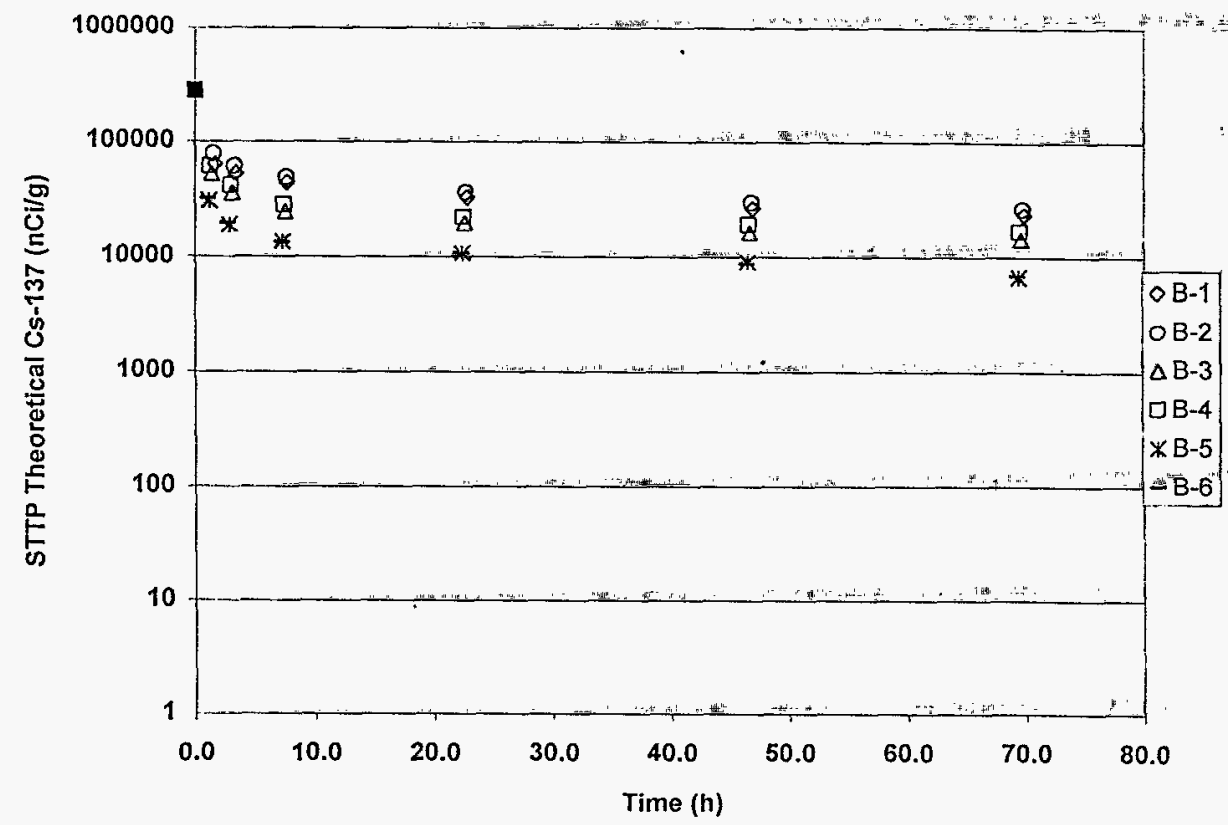


precipitates faster with an increase in the $\mathrm{K}^{+}: \mathrm{Cs}^{+}$ratio is attributed solely to the fact that an increased $\mathrm{K}^{+}$ concentration (relative to a stable $\mathrm{Cs}^{+}$concentration) requires a larger quantity of $\mathrm{NaTPB}$ to maintain the same percent excess NaTPB (i.e., the ratio of NaTPB to $\mathrm{Cs}^{+}$decreases as potassium increases).

\subsection{Test Set C: Effect of Mercury Concentration}

Figure 3 shows the influence of mercury content on the rate of cesium precipitation; Appendix $C$ contains the measured values. Mercury and potassium show similar minor effects.. Increased mercury (with a constant cesium concentration) results in an increased rate of cesium precipitation.

\subsection{Test Set D: Effect of Percent Excess Sodium Tetraphenylborate}

Appendix $\mathrm{D}$ contains the data from Test Set $\mathrm{D}$. Figure 4 also shows this information. The data indicate that the percent excess NaTPB provides a significant influence on the rate of precipitation of CsTPB. Of the six tests conducted at $5.0 \mathrm{M} \mathrm{Na}^{+}$, the two tests with a $100 \%$ excess of NaTPB achieved the target limit of $30 \mathrm{nCi} / \mathrm{g}$ in less than 48 hours. The test conducted with a $78 \%$ excess of NaTPB required between 47 and 70 hours to achieve the $30 \mathrm{nCi} / \mathrm{g}$ limit. Tests with 33 and $67 \%$ excess NaTPB did not achieve the 30 $\mathrm{nCi} / \mathrm{g}$ limit within three days.

\subsection{Test Set F: Effect of Increased Agitation}

Tests $F-1$ and $F-2$ shared the same composition as a set of eight other experiments (A-3, A-4, B-3, B-4, $\mathrm{C}-3, \mathrm{C}-4, \mathrm{D}-1$, and $\mathrm{D}-2)$. All used $33 \%$ excess NaTPB. However personnel stirred Tests $\mathrm{F}-1$ and $\mathrm{F}-2$ at $300 \mathrm{rpm}$ for the first 5 minutes, including the period of NaTPB addition, versus $70 \mathrm{rpm}$ for the other set. Figure 5 shows the cesium precipitation behavior. The results conclusively show that increased agitation during addition of NaTPB solution results in decontamination within 24 hours. Only one test (D-1) stirred at a rate of $70 \mathrm{rpm}$ achieved decontamination within 72 hours.

Figure 6 contains a similar comparison for tests using 100\% excess NaTPB. The two tests (i.e., F-3 and $\mathrm{F}-4)$ conducted with mixing at a rate of $300 \mathrm{rpm}$ achieved the target decontamination limit of $30 \mathrm{nCi} / \mathrm{g}$ in less than 1.5 hours. The tests mixed at a rate of $70 \mathrm{rpm}$ (i.e., D-5 and D-6) required between 22 and 47 hours to achieve decontamination.

Figure 3. Small Tank Tetraphenylborate Precipitation theoretical concentration of Cs-137 as a function of time and $\mathrm{Hg}^{2+}$. Tests $\mathrm{C}-1$ and $\mathrm{C}-2$ contained $1.2 \times 10^{-4} \mathrm{M} \mathrm{Hg}^{2+}, \mathrm{C}-3$ and $\mathrm{C}-4$ used $5.0 \times 10^{-4} \mathrm{M}$ $\mathrm{Hg}^{2+}$, while $\mathrm{C}-5$ and $\mathrm{C}-6$ held $20 \times 10^{-4} \mathrm{M} \mathrm{Hg}^{2+}$.

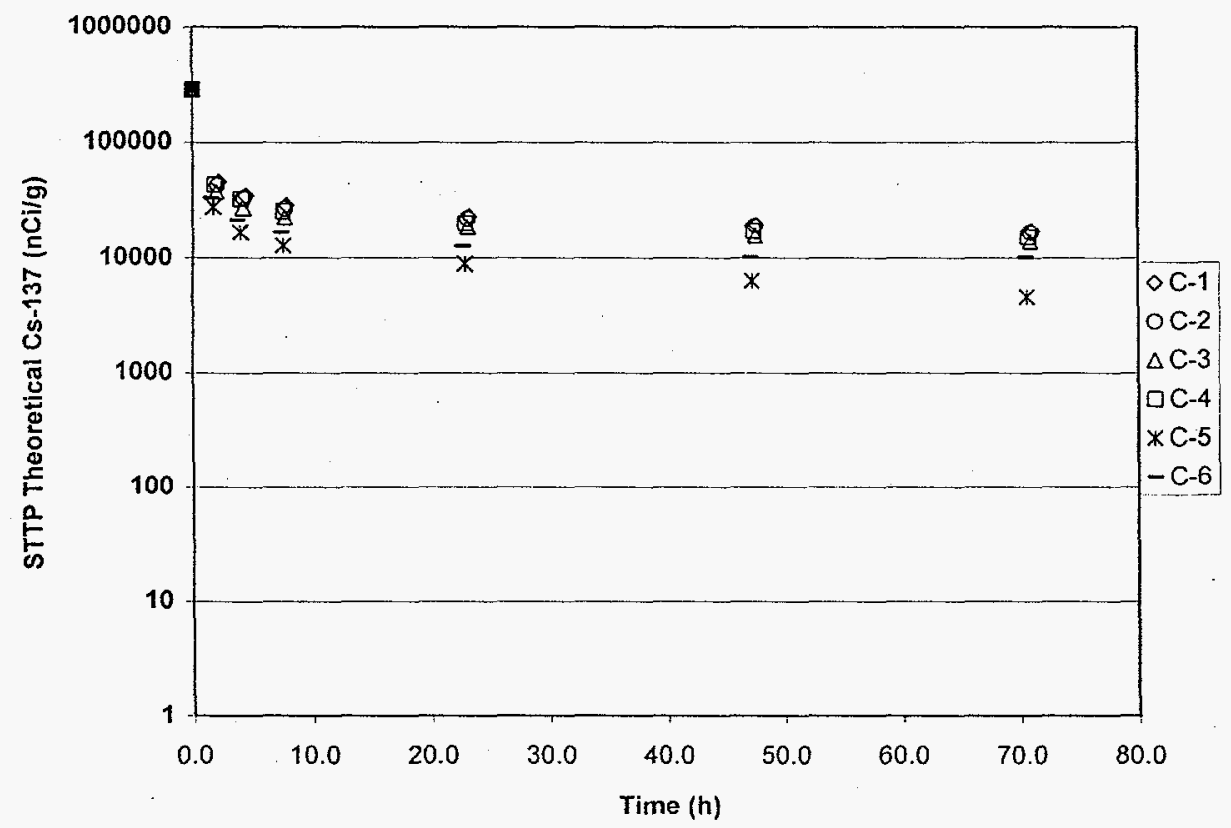


Page 8 of 20

Figure 4. Small Tank Tetraphenylborate Precipitation theoretical concentration of Cs-137 as a function of time and percent excess NaTPB. Tests D-1 and D-2 used 33\% excess NaTPB, D-3 added $67 \%$ excess NaTPB, D- 4 held $78 \%$ excess NaTPB, and D-5 and D-6 contained $100 \%$ excess NaTPB.

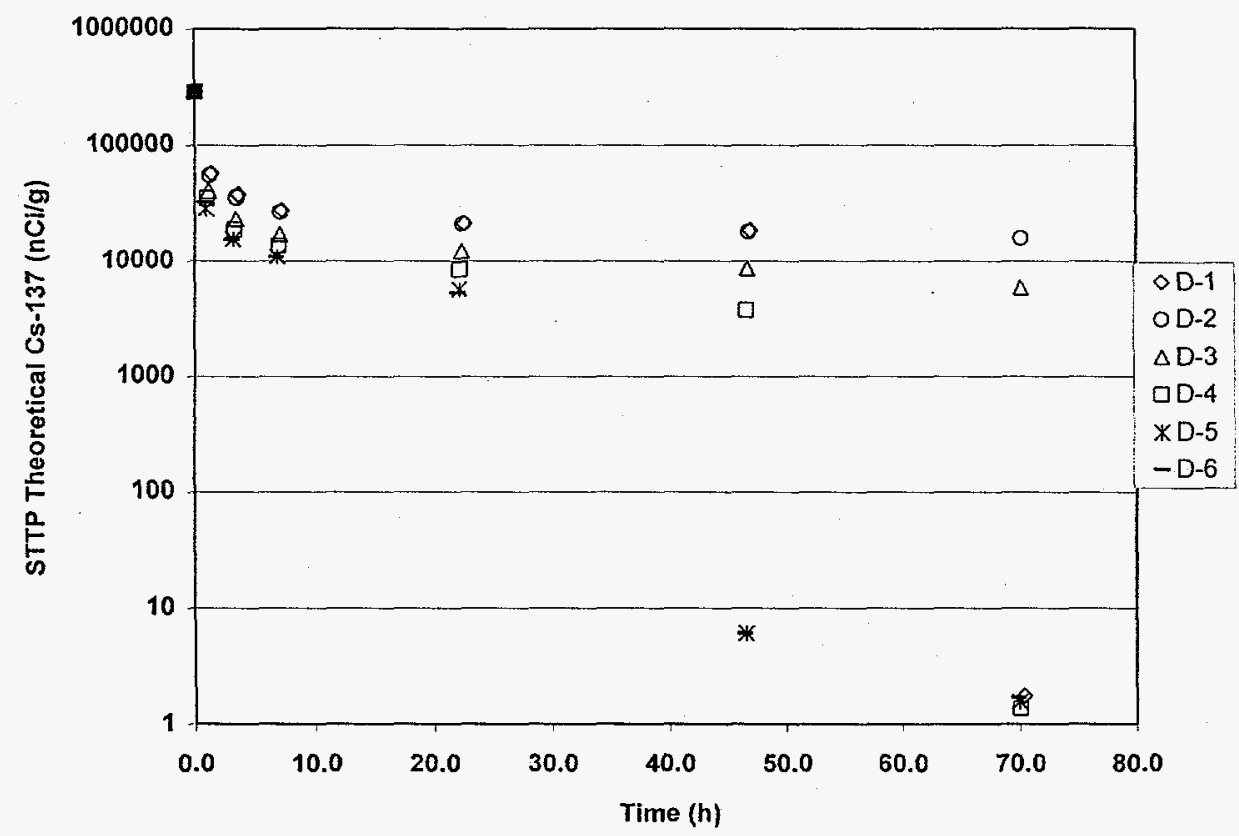

Figure 5. Small Tank Tetraphenylborate Precipitation theoretical concentration of Cs-137 as a function of time and agitation with $33 \%$ excess NaTPB. Tests A-3, A-4, B-3, B-4, C-3, C-4, D-1, and D-2 stirred initially at a rate of $70 \mathrm{rpm}$. Tests $F-1$ and $F-2$ stirred initially at a rate of $300 \mathrm{rpm}$.

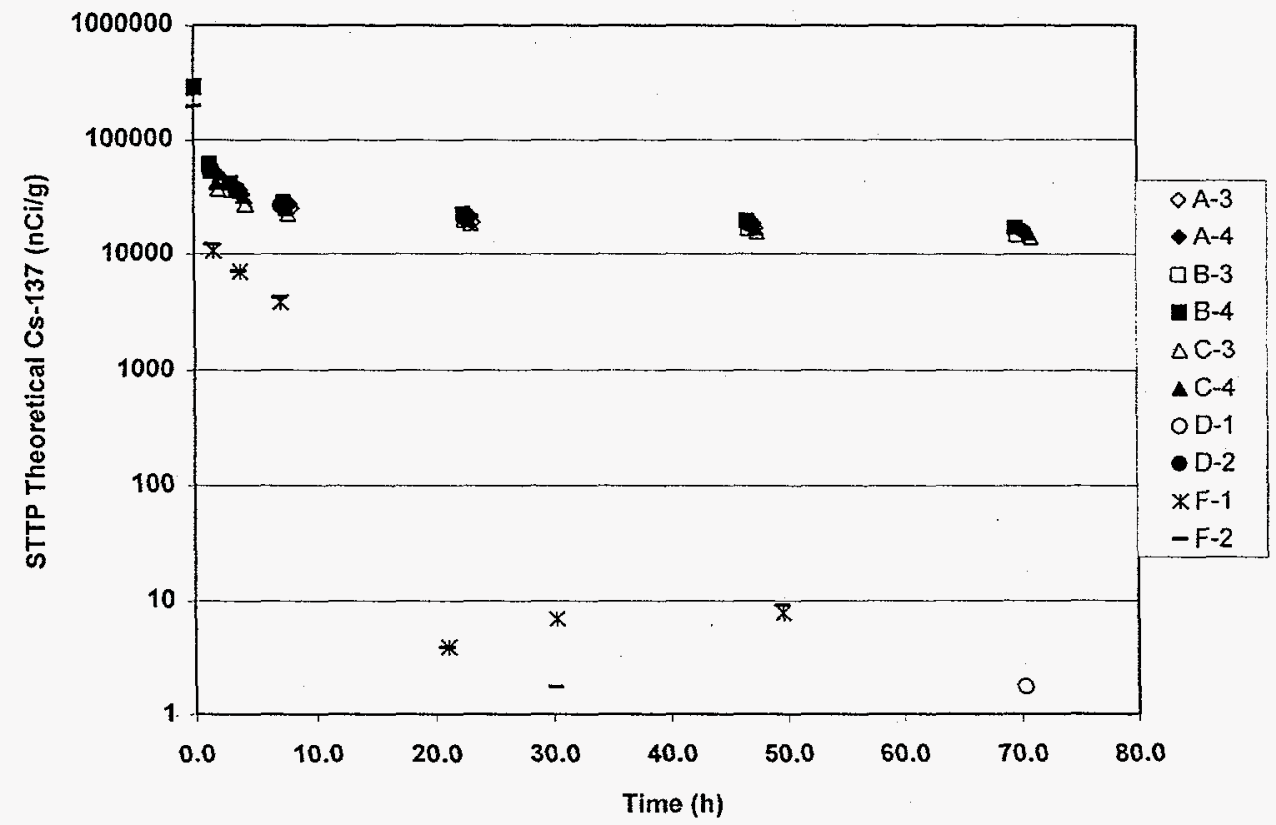


Figure 6. Small Tank Tetraphenylborate Precipitation theoretical concentration of Cs-137 as a function of time and agitation with $100 \%$ excess NaTPB. Tests D-5 and D-6 stirred initially at a rate of 70 rpm. Tests F-1 and F-2 stirred initially at a rate of $300 \mathrm{rpm}$.

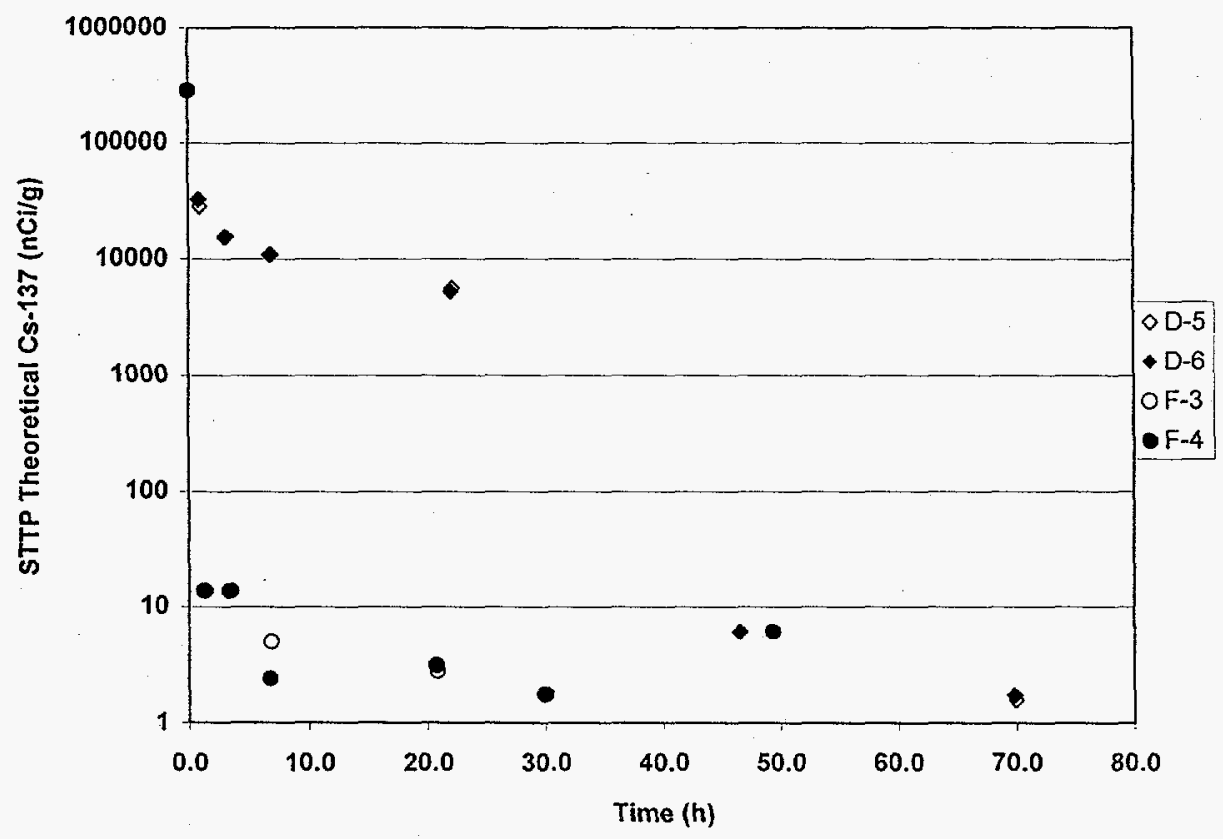

\subsection{Conclusions}

The data obtained from the tests described in this document provide results for determining tank size for design throughput of SRS waste in the proposed STTP facility. The data clearly indicate the following.

- The degree of agitation during addition of NaTPB significantly affects the rate of cesium precipitation.

- The $\mathrm{Na}^{+}$concentration of the waste solution moderately affects the rate of cesium precipitation.

- The percent excess of NaTPB moderately affects the rate of cesium precipitation.

- The ratio of $\mathrm{K}^{+}$to $\mathrm{Cs}^{+}$and $\mathrm{Hg}^{+2}$ to $\mathrm{Cs}^{+}$only slightly influence the rate of cesium precipitation.

- A target Cs-137 concentration of $30 \mathrm{nCi} / \mathrm{g}$ was achieved in less than $1.5 \mathrm{~h}$ with a $100 \%$ excess of $\mathrm{NaTPB}$ in a $5.0 \mathrm{M} \mathrm{Na}^{+}$solution when stirred at a rate of $300 \mathrm{rpm}$. A target Cs-137 concentration of 30 $\mathrm{nCi} / \mathrm{g}$ was achieved in less than $24 \mathrm{~h}$ with a $33 \%$ excess of NaTPB in a $5.0 \mathrm{M} \mathrm{Na}^{+}$solution when stirred at a rate of $300 \mathrm{rpm}$.

Data contained in this document addressed two of the three defined objectives. Mercury data was not available to address the third objective at the time this document was issued. This document will be revised upon receipt of that data. For the purpose of time and cost, this test program did not address the influence of temperature or order of chemical addition. Minimal risk is involved with these parameters since testing utilized a minimum bounding temperature of $25^{\circ} \mathrm{C}$ and the current planned order of chemical addition (i.e., NaTPB addition to salt solution waste). This is thought to be true since (1) the kinetics of precipitation should be faster at the potentially higher temperatures that will be observed in the plant and (2) the order of chemical addition performed in these tests (i.e., NaTPB to salt solution) should lead to slower kinetics than the reverse order (i.e., salt solution to NaTPB) because of NaTPB solubility and sodium ion concentration. 


\subsection{References}

1. P. L. Rutland et al., "Bases, Assumptions, and Results of the Flowsheet Calculations for the Initial Eighteen Salt Disposition Alternatives", WSRC-RP-98-00166, 25 June 1998.

2. P. L. Rutland, "Scoping Tests for Small Tank ITP-Salt Team Phase 3 Evaluation," HLE-TAR-98059, Rev. 0, July 14, 1998.

3. "Obtaining Analytical Services," Manual L1, Procedure 3.07, Rev. 1, November 1, 1996

4. "Technical Notebook Use," Manual L1, Procedure 4.19, Rev. 5, February 2, 1998. 
7.0 Tables

Table 1. Sodium ion test solution concentrations.

\begin{tabular}{|c|c|c|c|}
\hline Component & Concentration & Concentration & Concentration \\
\hline $\mathrm{Na}^{+}(\mathrm{M})$ & 4.0 & 5.0 & 6.0 \\
$\mathrm{~K}^{+}(\mathrm{M})$ & 0.013 & 0.013 & 0.013 \\
$\mathrm{Cs}^{+}(\mathrm{M})$ & 0.00013 & 0.00013 & 0.00013 \\
$\mathrm{OH}^{-}(\mathrm{M})$ & 1.36 & 1.71 & 2.05 \\
$\mathrm{NO}_{3}^{-}(\mathrm{M})$ & 1.53 & 1.91 & 2.29 \\
$\mathrm{NO}_{2}^{-}(\mathrm{M})$ & 0.37 & 0.46 & 0.56 \\
$\mathrm{AlO}_{3}^{-}(\mathrm{M})$ & 0.22 & 0.28 & 0.33 \\
$\mathrm{CO}_{3}^{2-}(\mathrm{M})$ & 0.11 & 0.14 & 0.17 \\
$\mathrm{SO}_{4}^{2-}(\mathrm{M})$ & 0.11 & 0.13 & 0.16 \\
$\mathrm{Cl}^{-}(\mathrm{M})$ & 0.018 & 0.022 & 0.027 \\
$\mathrm{~F}^{-}(\mathrm{M})$ & 0.023 & 0.029 & 0.034 \\
$\mathrm{PO}_{4}^{3-}(\mathrm{M})$ & 0.007 & 0.009 & 0.011 \\
$\mathrm{NaTPB}^{3} \%$ (xcess) & 33 & 33 & 33 \\
$\mathrm{Hg}^{2+}(\mathrm{M})^{\mathrm{b}}$ & $5.0 \times 10^{-4}$ & $5.0 \times 10^{-4}$ & $5.0 \times 10^{-4}$ \\
\hline
\end{tabular}

\% excess NaTPB relative to the amount required for precipitation of $\mathrm{K}^{+} \mathrm{Cs}^{+}$, and $\mathrm{Hg}^{2+}$.

b $5.0 \times 10^{-4}$ molar equals $100 \mathrm{mg} / \mathrm{L}$ mercury.

Table 2. Potassium ion test solution concentrations.

\begin{tabular}{|c|c|}
\hline Component & Concentration \\
\hline $\mathrm{Na}^{+}(\mathrm{M})$ & 5.0 \\
$\mathrm{~K}^{+}(\mathrm{M})$ & $\mathbf{0 . 0 0 3 3 , 0 . 0 1 3 , 0 . 0 5 2}$ \\
$\mathrm{Cs}^{+}(\mathrm{M})$ & 0.00013 \\
$\mathrm{OH}^{-}(\mathrm{M})$ & 1.71 \\
$\mathrm{NO}_{3}^{-}(\mathrm{M})$ & 1.91 \\
$\mathrm{NO}_{2}^{-}(\mathrm{M})$ & 0.46 \\
$\mathrm{AlO}_{2}^{-}(\mathrm{M})$ & 0.28 \\
$\mathrm{CO}_{3}^{2-}(\mathrm{M})$ & 0.14 \\
$\mathrm{SO}_{4}^{2-}(\mathrm{M})$ & 0.13 \\
$\mathrm{Cl}^{-}(\mathrm{M})$ & 0.022 \\
$\mathrm{~F}^{-}(\mathrm{M})$ & 0.029 \\
$\mathrm{PO}_{4}^{{ }^{3}}(\mathrm{M})$ & 0.009 \\
$\mathrm{NaTPB}(\%$ excess) & 33 \\
$\mathrm{Hg}^{2+}(\mathrm{M})^{\mathrm{b}}$ & $5.0 \times 10^{-4}$ \\
\hline
\end{tabular}

a excess NaTPB relative to the amount required for precipitation of $\mathrm{K}^{+}, \mathrm{Cs}^{+}$, and $\mathrm{Hg}^{2+}$.

${ }^{b} 5.0 \times 10^{-4}$ molar equals $100 \mathrm{mg} / \mathrm{L}$ mercury.

Table 3. Mercury ion test solution concentrations.

\begin{tabular}{|c|c|}
\hline Component & Concentration \\
\hline $\mathrm{Na}^{+}(\mathrm{M})$ & 5.0 \\
$\mathrm{~K}^{+}(\mathrm{M})$ & 0.013 \\
$\mathrm{Cs}^{+}(\mathrm{M})$ & 0.00013 \\
$\mathrm{OH}^{-}(\mathrm{M})$ & 1.71 \\
$\mathrm{NO}_{3}^{-}(\mathrm{M})$ & 1.91 \\
$\mathrm{NO}_{2}^{-}(\mathrm{M})$ & 0.46 \\
$\mathrm{AlO}_{2}^{-}(\mathrm{M})$ & 0.28 \\
$\mathrm{CO}_{3}^{3-}(\mathrm{M})$ & 0.14 \\
$\mathrm{SO}^{4-}(\mathrm{M})$ & 0.13 \\
$\mathrm{Cl}^{-}(\mathrm{M})$ & 0.022 \\
$\mathrm{~F}^{-}(\mathrm{M})$ & 0.029 \\
$\mathrm{PO}_{4}^{3-}(\mathrm{M})$ & 0.009 \\
$\mathrm{NaTPB}^{3} \%$ excess) & 33 \\
$\mathrm{Hg}^{2+}(\mathrm{M})^{\mathrm{b}}$ & $\mathbf{1 . 2 \times 1 0 ^ { - 4 }}$ \\
& $\mathbf{5 . 0 \times 1 0 ^ { - 4 }}$ \\
& $20 \times 10^{-4}$ \\
\hline
\end{tabular}

$\%$ excess NaTPB relative to the amount required for precipitation of $\mathrm{K}^{+}, \mathrm{Cs}^{+}$, and $\mathrm{Hg}^{2+}$.

b $1.2 \times 10^{-4}, 5.0 \times 10^{-4}$, and $20 \times 10^{-4}$ molar equals 25,100 , and $400 \mathrm{mg} / \mathrm{L}$ mercury. 
Table 4. Percent excess NaTPB test solution concentrations.

\begin{tabular}{|c|c|}
\hline Component & Concentration \\
\hline $\mathrm{Na}^{+}(\mathrm{M})$ & 5.0 \\
$\mathrm{~K}^{+}(\mathrm{M})$ & 0.013 \\
$\mathrm{Cs}^{+}(\mathrm{M})$ & 0.00013 \\
$\mathrm{OH}^{-}(\mathrm{M})$ & 1.71 \\
$\mathrm{NO}_{3}^{-}(\mathrm{M})$ & 1.91 \\
$\mathrm{NO}_{2}^{-}(\mathrm{M})$ & 0.46 \\
$\mathrm{AlO}_{3}^{-}(\mathrm{M})$ & 0.28 \\
$\mathrm{CO}_{3}^{2-}(\mathrm{M})$ & 0.14 \\
$\mathrm{SO}_{4}^{2-}(\mathrm{M})$ & 0.13 \\
$\mathrm{Cl}^{-}(\mathrm{M})$ & 0.022 \\
$\mathrm{~F}^{-}(\mathrm{M})$ & 0.029 \\
$\mathrm{PO}_{4}^{+3}(\mathrm{M})$ & 0.009 \\
$\mathrm{NaTPB}^{+} \%$ excess) & $\mathbf{3 3 , 6 7 , 7 8 , 1 0 0}$ \\
$\mathrm{Hg}^{2+}(\mathrm{M})^{\mathrm{b}}$ & $5.0 \times 10^{-4}$ \\
\hline
\end{tabular}

${ }^{2} \%$ excess NaTPB relative to the amount required for precipitation of $\mathrm{K}^{+}, \mathrm{Cs}^{+}$, and $\mathrm{Hg}^{2+}$.

${ }^{b} 5.0 \times 10^{-4}$ molar equals $100 \mathrm{mg} / \mathrm{L}$ mercury.

Table 5. Increased agitation test solution concentrations.

\begin{tabular}{|c|c|}
\hline Component & Concentration \\
\hline $\mathrm{Na}^{+}(\mathrm{M})$ & 5.0 \\
$\mathrm{~K}^{+}(\mathrm{M})$ & 0.013 \\
$\mathrm{Cs}^{+}(\mathrm{M})$ & 0.00013 \\
$\mathrm{OH}^{-}(\mathrm{M})$ & 1.71 \\
$\mathrm{NO}_{3}^{-}(\mathrm{M})$ & 1.91 \\
$\mathrm{NO}_{2}^{-}(\mathrm{M})$ & 0.46 \\
$\mathrm{AlO}_{3}^{-}(\mathrm{M})$ & 0.28 \\
$\mathrm{CO}_{3}^{2-}(\mathrm{M})$ & 0.14 \\
$\mathrm{SO}_{4}^{2-}(\mathrm{M})$ & 0.13 \\
$\mathrm{Cl}^{-}(\mathrm{M})$ & 0.022 \\
$\mathrm{~F}^{-}(\mathrm{M})$ & 0.029 \\
$\mathrm{PO}_{4}^{3-}(\mathrm{M})$ & 0.009 \\
$\mathrm{NaTPB}^{3-}$ excess) & 33,100 \\
$\mathrm{Hg}^{2+}(\mathrm{M})^{\mathrm{b}}$ & $5.0 \times 10^{-4}$ \\
\hline
\end{tabular}

\% excess NaTPB relative to the amount required for precipitation of $\mathrm{K}^{+}, \mathrm{Cs}^{+}$, and $\mathrm{Hg}^{2+}$.

b $5.0 \times 10^{-4}$ molar equals $100 \mathrm{mg} / \mathrm{L}$ mercury. 


\subsection{Appendices}

\subsection{Appendix A. Test Set A Data: Effect of Sodium Concentration}

\begin{tabular}{|c|c|c|c|c|c|}
\hline \multicolumn{6}{|c|}{ Test $A-1$} \\
\hline & Experimental & STTP & retical & & \\
\hline $\begin{array}{l}\text { Time } \\
\text { (h) }\end{array}$ & $\begin{array}{l}\mathrm{Cs}-137 \\
(\mathrm{nCi} / \mathrm{g})\end{array}$ & $\begin{array}{l}\mathrm{Cs}-137 \\
\text { (nCi/g) }\end{array}$ & $\begin{array}{c}\text { Cs }-137 \\
\text { DF }\end{array}$ & $\begin{array}{c}K \\
(M)\end{array}$ & $\begin{array}{l}\mathrm{Hg} \\
(\mathrm{M})\end{array}$ \\
\hline 0.0 & 380 & 287598 & 1 & NAá & NA \\
\hline 2.5 & 24.9 & 18861 & 15 & $\mathrm{NA}$ & NA \\
\hline 4.4 & 20.6 & 15572 & 18 & $N A$ & NA \\
\hline 8.4 & 15.5 & 11710 & 25 & $\mathrm{NA}$ & NA \\
\hline 23.6 & 8.28 & 6259 & 46 & NA & NA \\
\hline 47.7 & $<8.29 E-03$ & $<6.26$ & $>45913$ & NA & NA \\
\hline 70.7 & $<9.58 E-03$ & $<7.24$ & $>39711$ & NA & NA \\
\hline
\end{tabular}

anA indicates sample pending analysis.

\begin{tabular}{|c|c|c|c|c|c|}
\hline \multicolumn{7}{|c|}{ Test A-2 } & STTP Theoretical \\
\hline $\begin{array}{c}\text { Time } \\
\text { (h) }\end{array}$ & $\begin{array}{c}\text { Experimental } \\
\text { Cs-137 } \\
\text { (nCi/g) }\end{array}$ & $\begin{array}{c}\text { Ss-137 } \\
\text { (nCi/g) }\end{array}$ & $\begin{array}{c}\text { Cs-137 } \\
\text { DF }\end{array}$ & $\begin{array}{c}\mathrm{K} \\
\text { (M) }\end{array}$ & $\begin{array}{c}\mathrm{Hg} \\
\text { (M) }\end{array}$ \\
\hline 0.0 & 380 & 287356 & 1 & NAa & NA \\
\hline 2.3 & 23.8 & 17988 & 16 & NA & NA \\
\hline 4.1 & 17.8 & 13432 & 21 & NA & NA \\
\hline 8.2 & 12.9 & 9782 & 29 & NA & NA \\
\hline 23.4 & 5.50 & 4759 & 69 & NA & NA \\
\hline 47.5 & $<6.57 E-03$ & $<4.97$ & $>57841$ & NA & NA \\
\hline 70.5 & $<8.29 E-03$ & $<6.26$ & $>45874$ & NA & NA \\
\hline
\end{tabular}

anA indicates sample pending analysis.

\begin{tabular}{|c|c|c|c|c|c|}
\hline \multicolumn{6}{|c|}{ Test $\mathrm{A}-3$} \\
\hline & Experimental & STTP & retical & & \\
\hline $\begin{array}{c}\text { Time } \\
\text { (h) }\end{array}$ & $\begin{array}{l}\text { Cs-137 } \\
\text { (nCi/g) }\end{array}$ & $\begin{array}{l}\text { Cs-137 } \\
\text { (nCi/g) }\end{array}$ & $\begin{array}{c}\text { Cs-137 } \\
\text { DF }\end{array}$ & $\begin{array}{c}K \\
(M)\end{array}$ & $\begin{array}{l}\mathrm{Hg} \\
(\mathrm{M})\end{array}$ \\
\hline 0.0 & 375 & 283691 & 1 & NÁa & NA \\
\hline 2.1 & 57.4 & 43429 & 7 & NA & NA \\
\hline 3.9 & 44.5 & 33636 & 8 & NA & NA \\
\hline 8.1 & 33.5 & 25312 & 11 & NA & NA \\
\hline 23.3 & 25.1 & 18979 & 15 & NA & NA \\
\hline 47.3 & 22.5 & 16980 & 77 & NA & NA \\
\hline 70.3 & 19.9 & 15057 & 19 & NA & NA \\
\hline
\end{tabular}

alvA indicates sample pending analysis.

\begin{tabular}{|c|c|c|c|c|c|}
\hline \multicolumn{6}{|c|}{ Test $A-4$} \\
\hline & Experimental & STTP & retical & & \\
\hline $\begin{array}{l}\text { Time } \\
\text { (h) }\end{array}$ & $\begin{array}{l}\mathrm{Cs}-137 \\
\text { (nCi/g) }\end{array}$ & $\begin{array}{l}\mathrm{Cs}-137 \\
\text { (nCi/g) }\end{array}$ & $\begin{array}{c}\text { Cs-137 } \\
\text { DF }\end{array}$ & $\begin{array}{c}K \\
(M)\end{array}$ & $\begin{array}{l}\mathrm{Hg} \\
\text { (M) }\end{array}$ \\
\hline 0.0 & 375 & 283131 & 1 & NÁa & NAA \\
\hline 2.0 & 66.2 & 50064 & 6 & NA & NA \\
\hline 3.8 & 48.3 & 36509 & 8 & NA & NA \\
\hline 8.0 & 36.2 & 27399 & 10 & NA & NA \\
\hline 23.2 & 28.5 & 21520 & 13 & NA & NA \\
\hline 47.2 & 24.4 & 18446 & 15 & NA & NA \\
\hline 70.2 & 21.3 & 16124 & 18 & NA & NA \\
\hline
\end{tabular}

aNA indicates sample pending analysis. 


\begin{tabular}{|c|c|c|c|c|c|}
\hline \multicolumn{7}{|c|}{ Test A-5 } \\
\hline $\begin{array}{c}\text { Time } \\
\text { (h) }\end{array}$ & $\begin{array}{c}\text { Experimenta } \\
\text { Cs-137 } \\
\text { (nCi/g) }\end{array}$ & $\begin{array}{c}\text { STTP Theoretical } \\
\text { Cs-137 } \\
\text { (nCi/g) }\end{array}$ & $\begin{array}{c}\text { Cs-137 } \\
\text { DF }\end{array}$ & $\begin{array}{c}\mathrm{K} \\
(\mathrm{M})\end{array}$ & $\begin{array}{c}\mathrm{Hg} \\
\text { (M) }\end{array}$ \\
\hline 0.0 & 351 & 264999 & 1 & NA & NA \\
\hline 1.9 & 73.5 & 55552 & 5 & NA & NA \\
\hline 3.7 & 55.4 & 41864 & 6 & NA & NA \\
\hline 7.9 & 41.2 & 31160 & 9 & NA & NA \\
\hline 23.0 & 34.1 & 25803 & 10 & NA & NA \\
\hline 47.1 & 30.3 & 22926 & 12 & NA & NA \\
\hline 70.1 & 27.8 & 21050 & 13 & NA & NA \\
\hline
\end{tabular}

anA indicates sample pending analysis.

\begin{tabular}{|c|c|c|c|c|c|}
\hline \multicolumn{7}{|c|}{ Test A-6 } \\
\hline $\begin{array}{c}\text { Time } \\
\text { (h) }\end{array}$ & $\begin{array}{c}\text { Experimentai } \\
\text { Cs-137 } \\
\text { (nCi/g) }\end{array}$ & $\begin{array}{c}\text { STTP Theoretical } \\
\text { Cs-137 } \\
\text { (nCi/g) }\end{array}$ & $\begin{array}{c}\text { Cs-137 } \\
\text { DF }\end{array}$ & $\begin{array}{c}\mathrm{K} \\
(\mathrm{M})\end{array}$ & $\begin{array}{c}\text { Hg } \\
\text { (M) }\end{array}$ \\
\hline 0.0 & 360 & 272202 & 1 & NAa & NA \\
\hline 1.8 & 75.4 & 56973 & 5 & NA & NA \\
\hline 3.6 & 54.7 & 41344 & 7 & NA & NA \\
\hline 7.8 & 40.7 & 30800 & 9 & NA & NA \\
\hline 22.9 & 33.9 & 25628 & 11 & NA & NA \\
\hline 47.1 & 31.3 & 23631 & 12 & NA & NA \\
\hline 70.0 & 28.2 & 21340 & 13 & NA & NA \\
\hline
\end{tabular}

anA indicates sample pending analysis.

\subsection{Appendix B. Test Set B Data: Effect of Potassium Concentration}

\begin{tabular}{|c|c|c|c|c|c|}
\hline \multicolumn{7}{|c|}{ Test B-1 } \\
\hline $\begin{array}{c}\text { Time } \\
\text { (h) }\end{array}$ & $\begin{array}{c}\text { Experimentain } \\
\text { Cs-137 } \\
\text { (nCi/g) }\end{array}$ & $\begin{array}{c}\text { STTP Theoretical } \\
\text { Cs-137 } \\
\text { (nCi/g) }\end{array}$ & $\begin{array}{c}\text { Cs-137 } \\
\text { DF }\end{array}$ & $\begin{array}{c}\text { K } \\
\text { (M) }\end{array}$ & $\begin{array}{c}\text { Hg } \\
\text { (M) }\end{array}$ \\
\hline 0.0 & 377 & 284729 & 7 & NAa & NA \\
\hline 1.7 & 84.9 & 64217 & 4 & NA & NA \\
\hline 3.4 & 70.0 & 52900 & 5 & NA & NA \\
\hline 7.7 & 58.9 & 44547 & 6 & NA & NA \\
\hline 22.8 & 44.0 & 33231 & 9 & NA & NA \\
\hline 47.0 & 35.9 & 27139 & 10 & NA & NA \\
\hline 69.9 & 31.5 & 23791 & 12 & NA & NA \\
\hline
\end{tabular}

aNA indicates sample pending analysis.

\begin{tabular}{|c|c|c|c|c|c|}
\hline \multicolumn{7}{|c|}{ Test B-2 } \\
\hline $\begin{array}{c}\text { Time } \\
(\mathrm{h})\end{array}$ & $\begin{array}{c}\text { Experimental } \\
\text { Cs-137 } \\
(\mathrm{nCi} / \mathrm{g})\end{array}$ & $\begin{array}{c}\text { STTPTheoretical } \\
\text { Cs-137 } \\
(\mathrm{nCi} / \mathrm{g})\end{array}$ & $\begin{array}{c}\text { Cs-137 } \\
\mathrm{DF}\end{array}$ & $\begin{array}{c}\mathrm{K} \\
(\mathrm{M})\end{array}$ & $\begin{array}{c}\mathrm{Hg} \\
\text { (M) }\end{array}$ \\
\hline 0.0 & 375 & 283850 & 1 & NAa & NA \\
\hline 1.5 & 104.4 & 78901 & 4 & NA & NA \\
\hline 3.3 & 81.1 & 61345 & 5 & NA & NA \\
\hline 7.6 & 65.6 & 49622 & 6 & NA & NA \\
\hline 22.7 & 48.8 & 36913 & 8 & NA & NA \\
\hline 46.9 & 40.5 & 30655 & 9 & NA & NA \\
\hline 69.8 & 35.5 & 26863 & 11 & NA & NA \\
\hline
\end{tabular}

anA indicates sample pending analysis. 


\begin{tabular}{|c|c|c|c|c|c|}
\hline \multicolumn{6}{|c|}{ Test B-3 } \\
\hline & Experimental & STTP & etical & & \\
\hline$\underset{\text { (h) }}{\text { Time }}$ & $\begin{array}{l}\mathrm{Cs}-137 \\
(\mathrm{nCi} / \mathrm{g})\end{array}$ & $\begin{array}{l}\text { Cs-137 } \\
\text { (nCi/g) }\end{array}$ & $\begin{array}{c}\text { Cs-137 } \\
\text { DF }\end{array}$ & $\begin{array}{c}K \\
(M)\end{array}$ & $\begin{array}{l}\mathrm{Hg} \\
\text { (M) }\end{array}$ \\
\hline 0.0 & 384 & 290230 & 1 & NAa & NA \\
\hline 1.4 & 69.8 & 52758 & 6 & NA & NA \\
\hline 3.1 & 48.0 & 36297 & 8 & NA & NA \\
\hline 7.5 & 33.0 & 24930 & 12 & NA & NA \\
\hline 22.6 & 26.3 & 19903 & 15 & NA & NA \\
\hline 46.7 & 22.0 & 16635 & 77 & NA & NA \\
\hline 69.7 & 19.1 & 14462 & 20 & NA & NA \\
\hline
\end{tabular}

aNA indicates sample pending analysis.

\begin{tabular}{|c|c|c|c|c|c|}
\hline \multicolumn{7}{|c|}{ Test B-4 } & STTP Theoretical \\
\hline $\begin{array}{c}\text { Time } \\
\text { (h) }\end{array}$ & $\begin{array}{c}\text { Experimental } \\
\text { Cs-137 } \\
\text { (nCi/g) }\end{array}$ & $\begin{array}{c}\text { Cs-137 } \\
\text { (nCi/g) }\end{array}$ & $\begin{array}{c}\text { Cs-137 } \\
\text { DF }\end{array}$ & $\begin{array}{c}\mathrm{K} \\
\text { (M) }\end{array}$ & $\begin{array}{c}\text { Hg } \\
\text { (M) }\end{array}$ \\
\hline 0.0 & 379 & 286395 & 1 & NAa & NA \\
\hline 1.3 & 81.7 & 61752 & 5 & NA & NA \\
\hline 3.0 & 55.5 & 41989 & 7 & NA & NA \\
\hline 7.4 & 38.0 & 28702 & 10 & NA & NA \\
\hline 22.5 & 29.7 & 22468 & 13 & NA & NA \\
\hline 46.6 & 25.9 & 19583 & 15 & NA & NA \\
\hline 69.5 & 22.5 & 17040 & 17 & NA & NA \\
\hline
\end{tabular}

aNA indicates sample pending analysis.

\begin{tabular}{|c|c|c|c|c|c|}
\hline \multicolumn{6}{|c|}{ Test B-5 } \\
\hline & Experimental & STTP & etical & & \\
\hline $\begin{array}{l}\text { Time } \\
\text { (h) }\end{array}$ & $\begin{array}{l}\text { Cs-137 } \\
\text { (nCi/g) }\end{array}$ & $\begin{array}{l}\text { Cs-137 } \\
\text { (nCi/g) }\end{array}$ & $\begin{array}{c}\text { Cs-137 } \\
\text { DF }\end{array}$ & $\begin{array}{c}\mathrm{K} \\
(\mathrm{M})\end{array}$ & $\begin{array}{l}\mathrm{Hg} \\
\text { (M) }\end{array}$ \\
\hline 0.0 & 373 & 281638 & 1 & NAáa & NA \\
\hline 1.2 & 40.9 & 30919 & 9 & $\mathrm{NA}$ & NA \\
\hline 2.9 & 25.2 & 19018 & 15 & $\mathrm{NA}$ & NA \\
\hline 7.3 & 17.9 & 13531 & 21 & $\mathrm{NA}$ & NA \\
\hline 22.4 & 14.2 & 10757 & 26 & NA & NA \\
\hline 46.5 & 12.0 & 9103 & 31 & NA & NA \\
\hline 69.4 & 8.93 & 6752 & 42 & NA & $\mathrm{NA}$ \\
\hline
\end{tabular}

anA indicates sample pending analysis.

\begin{tabular}{|c|c|c|c|c|c|}
\hline \multicolumn{6}{|c|}{ Test B-6 } \\
\hline & Experimental & STTP & etical & & \\
\hline $\begin{array}{l}\text { Time } \\
\text { (h) }\end{array}$ & $\begin{array}{l}\text { Cs-137 } \\
(\mathrm{nCi} / \mathrm{g})\end{array}$ & $\begin{array}{l}\text { Cs-137 } \\
\text { (nCi/g) }\end{array}$ & $\begin{array}{c}\text { Cs-137 } \\
\text { DF }\end{array}$ & $\begin{array}{c}K \\
\text { (M) }\end{array}$ & $\begin{array}{l}\mathrm{Hg} \\
\text { (M) }\end{array}$ \\
\hline 0.0 & 377 & 284760 & 1 & NAá & NA \\
\hline 1.1 & 43.1 & 32553 & 9 & $N A$ & NA \\
\hline 2.7 & 26.3 & 19847 & 14 & NA & $\mathrm{NA}$ \\
\hline 7.2 & 77.8 & 13431 & 21 & NA & NA \\
\hline 22.3 & 14.4 & 10861 & 26 & NA & NA \\
\hline 46.4 & 17.6 & 8734 & 33 & NA & $\mathrm{NA}$ \\
\hline 69.3 & 9.13 & 6900 & 41 & NA & $N A$ \\
\hline
\end{tabular}

aNA indicates sample pending analysis. 


\subsection{Appendix C. Test Set C Data: Effect of Mercury Concentration}

\begin{tabular}{|c|c|c|c|c|c|}
\hline \multicolumn{6}{|c|}{ Test C-1 } \\
\hline & Experimental & STTP & retical & & \\
\hline $\begin{array}{l}\text { Time } \\
\text { (h) }\end{array}$ & $\begin{array}{l}\mathrm{Cs}-137 \\
(\mathrm{nCi} / \mathrm{g})\end{array}$ & $\begin{array}{l}\text { Cs-137 } \\
\text { (nCi/g) }\end{array}$ & $\begin{array}{c}\text { Cs }-137 \\
\text { DF }\end{array}$ & $\begin{array}{c}K \\
(M)\end{array}$ & $\begin{array}{l}\mathrm{Hg} \\
\text { (M) }\end{array}$ \\
\hline 0.0 & 376 & 284410 & 1 & NAa & NA \\
\hline 2.2 & 59.7 & 45096 & 6 & NA & NA \\
\hline 4.5 & 45.4 & 34308 & 8 & NA & NA \\
\hline 7.9 & 37.4 & 28283 & 10 & NA & NA \\
\hline 23.3 & 30.4 & 23006 & 12 & NA & NA \\
\hline 47.6 & 25.5 & 19315 & 15 & NA & $\mathrm{NA}$ \\
\hline 71.0 & 22.5 & 17013 & 17 & NA & NA \\
\hline
\end{tabular}

aNA indicates sample pending analysis.

\begin{tabular}{|c|c|c|c|c|c|}
\hline \multicolumn{6}{|c|}{ Test C-2 } \\
\hline $\begin{array}{c}\text { Time } \\
\text { (h) }\end{array}$ & $\begin{array}{c}\text { Experimental } \\
\text { Cs-137 } \\
\text { (nCi/g) }\end{array}$ & $\begin{array}{r}\text { STTP } \\
\mathrm{Cs}-137 \\
(\mathrm{nCi} / \mathrm{g})\end{array}$ & $\begin{array}{c}\text { etical } \\
\text { Cs-137 } \\
\text { DF }\end{array}$ & $\begin{array}{c}K \\
(M)\end{array}$ & $\begin{array}{l}\mathrm{Hg} \\
\text { (M) }\end{array}$ \\
\hline 0.0 & 376 & 284594 & 1 & NAa & $\mathrm{NA}$ \\
\hline 2.1 & 55.9 & 42236 & 7 & NA & NA \\
\hline 4.3 & 43.4 & 32796 & 9 & NA & NA \\
\hline 7.7 & 35.2 & 26600 & 11 & NA & NA \\
\hline 23.2 & 29.0 & 21961 & 13 & NA & NA \\
\hline 47.5 & 25.2 & 19070 & 15 & NA & NA \\
\hline 70.9 & 22.0 & 16621 & 77 & NA & NA \\
\hline
\end{tabular}

anA indicates sample pending analysis.

\begin{tabular}{|c|c|c|c|c|c|}
\hline \multicolumn{6}{|c|}{ Test C-3 } \\
\hline & Experimental & STTP & retical & & \\
\hline$\underset{\text { (h) }}{\text { Time }}$ & $\begin{array}{l}\mathrm{Cs}-137 \\
(\mathrm{nCi} / \mathrm{g})\end{array}$ & $\begin{array}{l}\text { Cs-137 } \\
\text { (nCi/g) }\end{array}$ & $\begin{array}{c}\text { Cs-137 } \\
\text { DF }\end{array}$ & $\underset{(M)}{K}$ & $\begin{array}{l}\mathrm{Hg} \\
\text { (M) }\end{array}$ \\
\hline 0.0 & 378 & 285688 & 1 & NAá & NंA \\
\hline 2.0 & 49.3 & 37274 & 8 & $\mathrm{NA}$ & NA \\
\hline 4.2 & 36.2 & 27340 & 10 & $\mathrm{NA}$ & NA \\
\hline 7.7 & 29.8 & 22540 & 13 & NA & $\mathrm{NA}$ \\
\hline 23.1 & 24.6 & 18578 & 15 & NA & NA \\
\hline 47.5 & 20.7 & 15660 & 18 & $\mathrm{NA}$ & NA \\
\hline 70.8 & 18.5 & 74005 & 20 & NA & NA \\
\hline
\end{tabular}

aNA indicates sample pending analysis.

\begin{tabular}{|c|c|c|c|c|c|}
\hline \multicolumn{6}{|c|}{ Test C-4 } \\
\hline & Experimental & STTP & retical & & \\
\hline $\begin{array}{c}\text { Time } \\
\text { (h) }\end{array}$ & $\begin{array}{l}\mathrm{Cs}-137 \\
(\mathrm{nCi} / \mathrm{g})\end{array}$ & $\begin{array}{l}\text { Cs-137 } \\
\text { (nCi/g) }\end{array}$ & $\begin{array}{c}\text { Cs-137 } \\
\text { DF }\end{array}$ & $\begin{array}{c}K \\
(M)\end{array}$ & $\begin{array}{l}\mathrm{Hg} \\
\text { (M) }\end{array}$ \\
\hline 0.0 & 382 & 288927 & 1 & NAá & NA \\
\hline 1.9 & 56.6 & 42822 & 7 & NA & NA \\
\hline 4.1 & 42.5 & 32152 & 9 & NA & NA \\
\hline 7.6 & 33.2 & 25084 & 12 & NA & NA \\
\hline 23.0 & 26.3 & 19917 & 15 & NA & NA \\
\hline 47.3 & 22.5 & 17042 & 17 & $\mathrm{NA}$ & NA \\
\hline 70.7 & 19.9 & 15070 & 19 & NA & NA \\
\hline
\end{tabular}

anA indicates sample pending analysis. 


\begin{tabular}{|c|c|c|c|c|c|}
\hline \multicolumn{6}{|c|}{ Test $\mathrm{C}-5$} \\
\hline & Experimental & STTP & retical & & \\
\hline $\begin{array}{l}\text { Time } \\
\text { (h) }\end{array}$ & $\begin{array}{l}\text { Cs-137 } \\
\text { (nCi/g) }\end{array}$ & $\begin{array}{l}\text { Cs-137 } \\
\text { (nCi/g) }\end{array}$ & $\begin{array}{c}\text { Cs-137 } \\
\text { DF }\end{array}$ & $\begin{array}{l}\mathrm{K} \\
\text { (M) }\end{array}$ & $\begin{array}{l}\mathrm{Hg} \\
\text { (M) }\end{array}$ \\
\hline 0.0 & 378 & 285399 & 1 & NAa & NÁ \\
\hline 1.7 & 36.5 & 27560 & 10 & NA & NA \\
\hline 4.0 & 22.1 & 16697 & 77 & NA & NA \\
\hline 7.5 & 16.9 & 32807 & 22 & NA & NA \\
\hline 22.9 & 11.8 & 8934 & 32 & NA & NA \\
\hline 47.2 & 8.5 & 6412 & 45 & NA & $\mathrm{NA}$ \\
\hline 70.6 & 6.17 & 4661 & 61 & NA & NA \\
\hline
\end{tabular}

aNA indicates sample pending analysis.

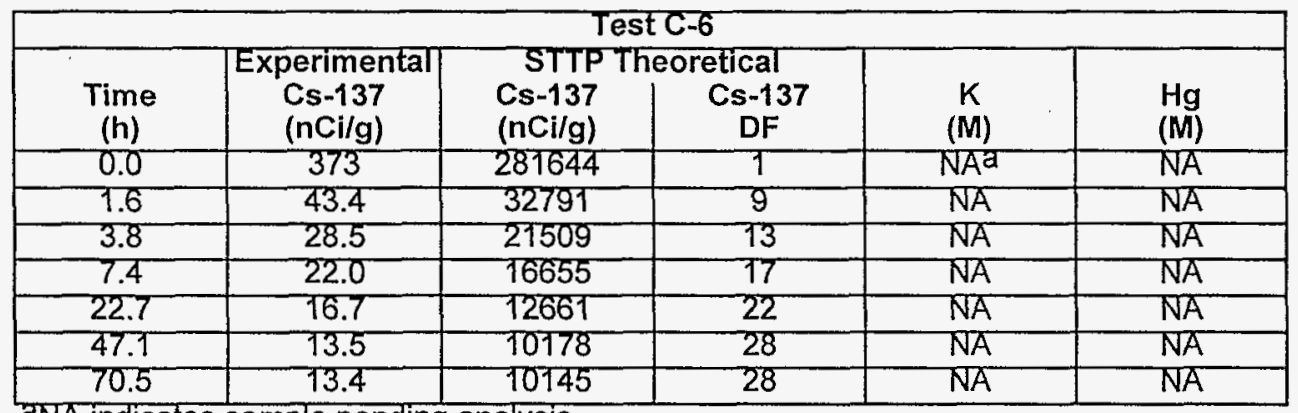

anA indicates sample pending analysis.

\subsection{Appendix D. Test Set D Data: Effect of Percent Excess Sodium Tetraphenylborate}

\begin{tabular}{|c|c|c|c|c|c|}
\hline \multicolumn{6}{|c|}{ Test D-1 } \\
\hline $\begin{array}{c}\text { Time } \\
\text { (h) }\end{array}$ & $\begin{array}{c}\text { Experimental } \\
\text { Cs-137 } \\
\text { (nCi/g) }\end{array}$ & $\begin{array}{r}\text { STTP } \\
\mathrm{Cs}-137 \\
(\mathrm{nCi} / \mathrm{g})\end{array}$ & $\begin{array}{c}\text { retical } \\
\text { Cs-137 } \\
\text { DF }\end{array}$ & $\begin{array}{c}K \\
(M)\end{array}$ & $\begin{array}{l}\mathrm{Hg} \\
\text { (M) }\end{array}$ \\
\hline 0.0 & 379 & 286880 & 1 & NAa & NÁ \\
\hline 1.4 & 75.5 & 57050 & 5 & NA & NA \\
\hline 3.6 & 49.6 & 37509 & 8 & NA & NA \\
\hline 7.2 & 36.4 & 27504 & 70 & $\mathrm{NA}$ & $\mathrm{NA}$ \\
\hline 22.6 & 27.9 & 21123 & 74 & $\mathrm{NA}$ & NA \\
\hline 47.0 & 24.4 & 78479 & 16 & NA & NA \\
\hline 70.3 & $<2.33 \mathrm{E}-03$ & $<1.76$ & $>162631$ & NA & NA \\
\hline
\end{tabular}

aNA indicates sample pending analysis.

\begin{tabular}{|c|c|c|c|c|c|}
\hline \multicolumn{6}{|c|}{ Test D-2 } \\
\hline & Experimental & STTP & retical & & \\
\hline $\begin{array}{c}\text { Time } \\
\text { (h) }\end{array}$ & $\begin{array}{l}\text { Cs-137 } \\
\text { (nCi/g) }\end{array}$ & $\begin{array}{l}\text { Cs-137 } \\
\text { (nCi/g) }\end{array}$ & $\begin{array}{c}\text { Cs-137 } \\
\text { DF }\end{array}$ & $\begin{array}{c}K \\
\text { (M) }\end{array}$ & $\begin{array}{l}\mathrm{Hg} \\
\text { (M) }\end{array}$ \\
\hline 0.0 & 380 & 287231 & 1 & NAa & NA \\
\hline 7.3 & 72.4 & 54761 & 5 & $N A$ & NA \\
\hline 3.5 & 47.1 & 35627 & 8 & NA & NA \\
\hline 7.1 & 35.0 & 26480 & 71 & NA & NA \\
\hline 22.5 & 27.8 & 21012 & 74 & NA & $\mathrm{NA}$ \\
\hline 46.8 & 23.7 & 77945 & 76 & NA & NA \\
\hline 70.2 & 20.9 & 15834 & 18 & NA & NA \\
\hline
\end{tabular}

aNA indicates sample pending analysis. 


\begin{tabular}{|c|c|c|c|c|c|}
\hline \multicolumn{7}{|c|}{ Test D-3 } \\
\hline $\begin{array}{c}\text { Time } \\
\text { (h) }\end{array}$ & $\begin{array}{c}\text { Experimental } \\
\text { Cs-137 } \\
\text { (nCi/g) }\end{array}$ & $\begin{array}{c}\text { STTP Theorefical } \\
\text { Cs-137 } \\
\text { (nCi/g) }\end{array}$ & $\begin{array}{c}\text { Cs-137 } \\
\text { DF }\end{array}$ & $\begin{array}{c}\mathrm{K} \\
(\mathrm{M})\end{array}$ & $\begin{array}{c}\mathrm{Hg} \\
\text { (M) }\end{array}$ \\
\hline 0.0 & 383 & 289628 & 1 & NAa & NA \\
\hline 1.2 & 53.4 & 40399 & 7 & NA & NA \\
\hline 3.4 & 30.6 & 23152 & 13 & NA & NA \\
\hline 7.0 & 22.6 & 17109 & 17 & NA & NA \\
\hline 22.4 & 16.2 & 12253 & 24 & NA & NA \\
\hline 46.7 & 11.4 & 8595 & 34 & NA & NA \\
\hline 70.1 & 7.79 & 5890 & 49 & NA & NA \\
\hline
\end{tabular}

\begin{tabular}{|c|c|c|c|c|c|}
\hline \multicolumn{6}{|c|}{ Test D-4 } \\
\hline & Experimental & STTP & retical & & \\
\hline $\begin{array}{l}\text { Time } \\
\text { (h) }\end{array}$ & $\begin{array}{l}\text { Cs-137 } \\
\text { (nCilg) }\end{array}$ & $\begin{array}{l}\text { Cs-137 } \\
\text { (nCilg) }\end{array}$ & $\begin{array}{c}\text { Cs-137 } \\
\text { DF }\end{array}$ & $\begin{array}{c}K \\
\text { (M) }\end{array}$ & $\begin{array}{l}\mathrm{Hg} \\
(\mathrm{M})\end{array}$ \\
\hline 0.0 & 384 & 290083 & 1 & NAa & NA \\
\hline 1.0 & 45.9 & 34678 & 8 & NA & NA \\
\hline 3.3 & 24.6 & 18580 & 16 & NA & NA \\
\hline 6.9 & 17.9 & 13526 & 21 & NA & NA \\
\hline 22.3 & 11.2 & 8452 & 34 & NA & NA \\
\hline 46.6 & 4.94 & 3736 & 78 & NA & NA \\
\hline 70.0 & $<1.80 \mathrm{E}-03$ & $<1.36$ & $>212595$ & NA & NA \\
\hline
\end{tabular}

anA indicates sample pending analysis.

\begin{tabular}{|c|c|c|c|c|c|}
\hline \multicolumn{6}{|c|}{ Test D-5 } \\
\hline & Experimental & STTP & Sretical & & \\
\hline $\begin{array}{l}\text { Time } \\
\text { (h) }\end{array}$ & $\begin{array}{l}\text { Cs-137 } \\
\text { (nCilg) }\end{array}$ & $\begin{array}{l}\text { Cs-137 } \\
\text { (nCi/g) }\end{array}$ & $\begin{array}{c}\text { Cs-137 } \\
\text { DF }\end{array}$ & $\begin{array}{l}\mathrm{K} \\
\text { (M) }\end{array}$ & $\begin{array}{l}\mathrm{Hg} \\
\text { (M) }\end{array}$ \\
\hline 0.0 & 378 & 285860 & 1 & NAa & NA \\
\hline 0.9 & 37.4 & 28289 & 70 & NA & NA \\
\hline 3.2 & 20.5 & 15492 & 18 & NA & NA \\
\hline 6.8 & 14.5 & 10949 & 26 & NA & NA \\
\hline 22.2 & 7.51 & 5680 & 50 & NA & NA \\
\hline 46.5 & $<8.02 E-03$ & $<6.06$ & $>47169$ & NA & NA \\
\hline 69.9 & $<2.08 \mathrm{E}-03$ & $<1.57$ & $>181676$ & NA & $\mathrm{NA}$ \\
\hline
\end{tabular}

aNA indicates sample pending analysis.

\begin{tabular}{|c|c|c|c|c|c|}
\hline \multicolumn{7}{|c|}{ Test D-6 } \\
\hline $\begin{array}{c}\text { Time } \\
\text { (h) }\end{array}$ & $\begin{array}{c}\text { Experimenta| } \\
\text { Cs-137 } \\
\text { (nCi/g) }\end{array}$ & $\begin{array}{c}\text { STTP Theoretical } \\
\text { Cs-137 } \\
\text { (nCi/g) }\end{array}$ & $\begin{array}{c}\text { Cs-137 } \\
\text { DF }\end{array}$ & $\begin{array}{c}\mathrm{K} \\
\text { (M) }\end{array}$ & $\begin{array}{c}\mathrm{Hg} \\
\text { (M) }\end{array}$ \\
\hline 0.0 & 384 & 290021 & 1 & NAa & NA \\
\hline 0.8 & 42.8 & 32368 & 9 & NA & NA \\
\hline 3.0 & 20.4 & 15422 & 19 & NA & NA \\
\hline 6.8 & 14.4 & 10899 & 27 & NA & NA \\
\hline 22.1 & 7.02 & 5306 & 55 & NA & NA \\
\hline 46.4 & $<8.02 E-03$ & $<6.06$ & $>47856$ & NA & NA \\
\hline 69.8 & $<2.27$-03 & $<1.77$ & $>169125$ & NA & NA \\
\hline
\end{tabular}


8.5 Appendix F. Test Set F Data: Effect of Increased Agitation

\begin{tabular}{|c|c|c|c|c|c|}
\hline \multicolumn{6}{|c|}{ Test F-1 } \\
\hline & Experimenta! & STTP & retical & & \\
\hline $\begin{array}{l}\text { Time } \\
\text { (h) }\end{array}$ & $\begin{array}{l}\mathrm{Cs}-137 \\
(\mathrm{nCi} / \mathrm{g})\end{array}$ & $\begin{array}{l}\text { Cs-137 } \\
\text { (nCi/g) }\end{array}$ & $\begin{array}{c}\text { Cs }-137 \\
\text { DF }\end{array}$ & $\begin{array}{c}\mathrm{K} \\
\text { (M) }\end{array}$ & $\begin{array}{l}\mathrm{Hg} \\
\text { (M) }\end{array}$ \\
\hline 0.0 & 379 & 286672 & 1 & NAa & NA \\
\hline 1.6 & 14.1 & 10637 & 27 & NA & $\mathrm{NA}$ \\
\hline 3.8 & 9.36 & 7079 & 40 & NA & $N A$ \\
\hline 7.1 & 5.03 & 3806 & 75 & NA & NA \\
\hline 21.1 & $<5.19 E-03$ & $<3.92$ & $>73105$ & NA & NA \\
\hline 30.3 & $<9.27 \mathrm{E}-03$ & $<7.01$ & $>40913$ & $\mathrm{NA}$ & NA \\
\hline 49.6 & $<1.04 E-02$ & $<7.87$ & $>36438$ & NA & NA \\
\hline
\end{tabular}

aNA indicates sample pending analysis.

\begin{tabular}{|c|c|c|c|c|c|}
\hline \multicolumn{6}{|c|}{ Test F-2 } \\
\hline & Experimental & STTP & retical & & \\
\hline $\begin{array}{l}\text { Time } \\
\text { (h) }\end{array}$ & $\begin{array}{l}\text { Cs-137 } \\
\text { (nCi/g) }\end{array}$ & $\begin{array}{l}\text { Cs-137 } \\
\text { (nCi/g) }\end{array}$ & $\begin{array}{c}\text { Cs-137 } \\
\text { DF }\end{array}$ & $\begin{array}{l}K \\
\text { (M) }\end{array}$ & $\begin{array}{l}\mathrm{Hg} \\
(\mathrm{M})\end{array}$ \\
\hline 0.0 & 261 & 197629 & 1 & NAa & NA \\
\hline 1.5 & 16.1 & 12190 & 16 & $\mathrm{NA}$ & NA \\
\hline 3.7 & 9.50 & 7186 & 28 & NA & NA \\
\hline 7.0 & 5.59 & 4225 & 47 & NA & NA \\
\hline 21.0 & $<5.19 E-03$ & $<3.92$ & $>50398$ & NA & NA \\
\hline 30.2 & $<2.33 E-03$ & $<1.76$ & $>112035$ & NA & $\mathrm{NA}$ \\
\hline 49.5 & $<1.22 E-02$ & $<9.22$ & $>21436$ & NA & NA \\
\hline
\end{tabular}

aNA indicates sample pending analysis.

\begin{tabular}{|c|c|c|c|c|c|}
\hline \multicolumn{6}{|c|}{ Test F-3 } \\
\hline & Experimental & STTP & retical & & \\
\hline $\begin{array}{c}\text { Time } \\
\text { (h) }\end{array}$ & $\begin{array}{l}\text { Cs-137 } \\
\text { (nCi/g) }\end{array}$ & $\begin{array}{l}\text { Cs-137 } \\
\text { (nCi/g) }\end{array}$ & $\begin{array}{c}\text { Cs-137 } \\
\text { DF }\end{array}$ & $\begin{array}{c}K \\
(M)\end{array}$ & $\begin{array}{l}\mathrm{Hg} \\
\text { (M) }\end{array}$ \\
\hline 0.0 & 381 & 287852 & 1 & NAa & $\mathrm{NA}$ \\
\hline 1.3 & $<1.83 E-02$ & $<13.8$ & $>20815$ & NA & NA \\
\hline 3.5 & $<1.83$ E-02 & $<13.8$ & $>20815$ & NA & NA \\
\hline 6.8 & $<6.59 E-03$ & $<4.98$ & $>57747$ & $\mathrm{NA}$ & NA \\
\hline 20.9 & $<3.72 E-03$ & $<2.81$ & $>102479$ & NA & NA \\
\hline 30.0 & $<2.33 E-03$ & $<1.76$ & $>163181$ & NA & NA \\
\hline 49.4 & $<8.02$ E-03 & $<6.06$ & $>47498$ & NA & NA \\
\hline
\end{tabular}

aNA indicates sample pending analysis.

\begin{tabular}{|c|c|c|c|c|c|}
\hline \multicolumn{6}{|c|}{ Test F-4 } \\
\hline & Experimental & STTP & oretical & & \\
\hline $\begin{array}{l}\text { Time } \\
\text { (h) }\end{array}$ & $\begin{array}{l}\text { Cs-137 } \\
\text { (nCi/g) }\end{array}$ & $\begin{array}{l}\text { Cs-137 } \\
\text { (nCi/g) }\end{array}$ & $\begin{array}{c}\text { Cs-137 } \\
\text { DF }\end{array}$ & $\begin{array}{c}K \\
(M)\end{array}$ & $\begin{array}{l}\mathrm{Hg} \\
(\mathrm{M})\end{array}$ \\
\hline 0.0 & 378 & 285799 & 1 & NAa & NA \\
\hline 1.2 & $<1.83 E-02$ & $<\sqrt{3.8}$ & $>20666$ & NA & NA \\
\hline 3.4 & $<1.83 \mathrm{E}-02$ & $<13.8$ & $>20666$ & NA & NA \\
\hline 6.7 & $<3.21 E-03$ & $<2.43$ & $>117719$ & NA & $N A$ \\
\hline 20.8 & $<4.15 E-03$ & $<3.13$ & $>91175$ & NA & NA \\
\hline 29.9 & $<2.33 E-03$ & $<1.76$ & $>162017$ & NA & NA \\
\hline 49.3 & $<8.02 E-03$ & $<6.06$ & $>47159$ & NA & $N A$ \\
\hline
\end{tabular}

aNA indicates sample pending analysis. 


\subsection{Distribution}

CC: G. E. Abell, 704-3N

B. N. Attaway, 773-A

J. L. Barnes, $704-3 \mathrm{~N}$

M. J. Barnes, 773-A

S. B. Beck, $704-3 \mathrm{~N}$

N. E. Bibler, 773-A

J. D. Carlson, $703-\mathrm{H}$

J. T. Carter, 704-25S

G. L. Cauthen, 241-119H

W. C. Clark, $704-56 \mathrm{H}$

C. L. Crawford, 773-41A

Dr. E. Cussler, 704-3N

N. R. Davis, 703-H

R. A. Dimenna, $773-42 \mathrm{~A}$

L. O. Dworjanyn, $779-2 A$

R. E. Eibling, 704-T

H. H. Elder, 704-S

S. D. Fink, 773-A

F. Fondeur, 773-62A

J. R. Fowler, 704-3N

M. W. Geeting, 773-24A

J. C. Griffin, 773-A

T. Hang, 773-42A

D. T. Hobbs, 773-A

E. W. Holtzscheiter, 773-A

P. I. Hudson, $704-3 \mathrm{~N}$

R. A. Jacobs, 704-3N

M. D. Johnson, 703-H

M. T. Keefer, 241-153H

P. S. Kirkland, 703-46A

E. J. Kosiancic, 704-3N

L. F. Landon, 704-T

B. L. Lewis, 703-H
T. J. Lex, 703-H

- P. E. Lowe, 773-41A

D. J. McCabe, 773-42A

J. W. McCollough, 703-H

M. S. Miller, $704-56 \mathrm{H}$

T. M. Monahon, 703-H

J. P. Morin, 703-H

E. T. Murphy, 704-3N

C. A. Nash, 773-42A

L. M. Nelson, 773-43A

L. M. Papouchado, 773-A

P. K. Paul, 773-42A

R. A. Peterson, 773-A

S. F. Piccolo, 704-3N

M. R. Poirier, 676-T

M. J. Polochko, 773-A

K. J. Rueter, 706-S

P. L. Rutland, 704-196N

R. H. Spires, 703-H

W. E. Stevens, 773-A

P. C. Suggs, $704-3 \mathrm{~N}$

R. F. Swingle, 773-A

W. L. Tamosaitis, 773-A

G. A. Taylor, $704-196 \mathrm{~N}$

W. B. VanPelt, 676-1T

D. D. Walker, 773-A

Dr. J. Watson, 704-3N

W. R. Wilmarth, 773-42A

G. T. Wright, 773-A

J. E. Young, 773-A

TIM, 703-43A

WPTS Files, 773-A, c/o S. Poston, 773-A

ITP files, c/o A. G. Wiest, 241-119H 